The determinants of student mobility in Europe: the quality dimension

Linda Van Bouwel and Reinhilde Veugelers

DEPARTMENT OF MANAGERIAL ECONOMICS, STRATEGY AND INNOVATION (MSI) 


\title{
The Determinants of Student Mobility in Europe: The Quality Dimension
}

\section{LINDA VAN BOUWEL ${ }^{a}$ and REINHILDE VEUGELERS ${ }^{\mathrm{a}} \mathrm{c}$}

a Katholieke Universiteit Leuven, Department of Managerial Economics, Strategy \& Innovation, Naamsestraat 69, 3000 Leuven, Belgium

${ }^{\mathrm{b}}$ Bruegel, Rue de la Charité 33, 1210 Brussels, Belgium

${ }^{\mathrm{c}}$ Centre for Economic Policy Research, 77 Bastwick Street, London, UK

(corresponding author: Linda Van Bouwel, e-mail: linda.vanbouwel@econ.kuleuven.be, tel.: +32 16 326862, fax: +32 16326732 )

\begin{abstract}
The Bologna Process in Europe aims to increase student mobility, with the purpose of increasing average university quality through fiercer competition for students in a larger, more unified market. However, this beneficial effect of increased student mobility will only occur if student mobility is guided by quality considerations. We examine whether the quality of a country's higher education system drives macro-flows of foreign tertiary students in Europe. Using various measures for the quality of a country's higher education system in an extended gravity model, we find that quality has a positive and significant effect on the size and direction of flows of students exchanged between 31 European countries. At the graduate level, however, the driving force for student mobility appears to be the lack of educational opportunities in the home country.
\end{abstract}

JEL codes: F22, I23, J61

Keywords: school choice, economies of scale, human capital 


\section{Introduction}

In European policy documents, research and higher education are identified as central to help turn the EU into the most competitive economy and knowledge-based society of the 21st century ${ }^{1}$. But in a European higher education and research area that still remains too fragmented, European universities currently do not seem to be in a position to achieve their potential. Whereas the United States experienced a rapid geographic integration in the second half of the twentieth century (Hoxby, 2002), Europe's higher education market has remained largely segmented into national or regional markets (Musselin, 2004). Operating in segmented local markets, European universities do not have sufficient incentives to develop their strengths. As a result, compared with their counterparts in the US and perhaps soon also China, they run the risk of falling behind in the increased international competition for talented academics and students.

Redressing this fragmentation has been high on the European policy agenda, with mobility of students and researchers a main policy target. The EU's research policy revolves around the building of a European integrated Research and Higher Education Area. The "2020 vision of ERA" (European Research Area), with its "fifth freedom" concept, or free circulation of knowledge, explicitly targets the integration into a single market for research by improving the mobility of scientific talents. Also the Bologna process, which currently covers 47 European countries, tries to improve the comparability and compatibility of Europe's diverse higher education systems, thus facilitating the mobility of students, graduates and higher education staff.

\footnotetext{
${ }^{1}$ See, for example, the EU's Communication on the EU2020 strategy (http://ec.europa.eu/europe2020/index_en.htm).
} 
In an integrated market, increased mobility should lead universities to offer a more open and challenging environment to be attractive. Through fiercer competition between a larger number of institutions for the best students and researchers, the overall quality of European universities should increase (Eurydice, 2010). However, for this beneficial effect to occur, two conditions must be satisfied: talents should not only be internationally mobile, but they should also be guided by quality in their choice of university.

The purpose of this paper is to examine whether the quality of the higher education system indeed drives the international mobility of students at the European level. We use an extended gravity model to assess the extent to which flows of students between a sample of European countries can be related to the quality of universities. We

use three different measures as quality indicators: the relative impact of a country's scientific publications, the number of universities a country has in the top 200 of the Shanghai ranking and the number of universities a country has in the Times Higher Education ranking. We find that the first two quality indicators have a positive and significant effect on the size and direction of student flows, whereas the third does not have an additional significant impact after controlling for the 'UK-effect'.

The remainder of this paper is organized as follows: section 2 provides an overview of the relevant literature on student mobility. Methodology and data are discussed in section 3, the empirical results in section 4. Section 5 concludes.

\section{Literature review}

Various strands of the economic literature study the factors which influence the choice of higher education from different perspectives. The closest link between students' higher education choices and quality of education is provided by the human capital theory of education (e.g. Becker, 1964; Freeman, 1986). In this perspective, individuals consider 
education as an investment decision with education directly increasing their human capital. Students will bear the costs of higher education in order to increase their future earnings and employment opportunities. Within a human capital perspective, students will prefer to attend a high-quality institution if any possible higher costs are compensated by higher returns. Krueger and Lindahl (2001), surveying the empirical evidence on monetary returns from education confirm the productivity enhancing effects of higher education as witnessed by a higher education wage premium. Furthermore, the quality of the institution indeed seems to increase returns: a degree from a renowned university is likely to enhance students' salary prospects and open doors to interesting jobs (Brewer et al., 1999). At least in the US, students are indeed found to match universities in terms of quality (Hoxby, 2005; Epple et al., 2006). In the signaling perspective to education (Spence, 1973), high-quality institutions will attract more students, if a degree from such an institution provides a stronger signal of intrinsic productivity of students to potential employers. In contrast, treating the choice to pursue higher education from a pure consumption perspective, predicts a negative relationship, as the demand for high-quality institutions will be negatively related to the higher costs to study at these institutions.

A student that considers attending a higher education programme in a different location than the home country must incorporate extra costs of international mobility into her investment decision. These mobility costs increase with geographic and cultural distance between home and the destination country. All else equal, internationally mobile students should be more sensitive to the quality dimension, as higher expected returns to education must compensate for the higher costs they incur.

The empirical literature on student mobility can roughly be divided into two strands: the literature on international student mobility, and the literature on domestic student 
mobility, i.e. on migration of students across regions within a country. Although our study is concerned with the former type of student mobility, we start with the latter strand of the literature, as it includes more prominently the quality dimension as an influencing factor than the former studies.

Most of the domestic mobility studies analyze student flows on the level of individual institutions in the considered region. The evidence of the effect of university quality on the number of students a university attracts from outside its home region is mixed. Abbott and Schmid (1975) find that university prestige accounts for only a modest proportion of interstate migration of students in the United States. In a study of Dutch regional student flows, Sá et al. (2004) find that students are not guided by the educational quality of university programmes, but rather by the availability of urban amenities, thus supporting the consumption perspective of higher education over the investment perspective. Faggian et al. (2007) find that Scottish and Welsh students that are able to enter a high-quality university in their home region are less likely to move away for higher education. By contrast, Ono (2001) finds that quality differentials significantly increase the likelihood that Japanese students move away from their home region for higher education. Similarly, McCann and Sheppard (2001) show that better higher education institutions generate more domestic migration for a sample of UK graduates.

Compared to domestic student mobility, the quality dimension should be more prominent in international student mobility. Nevertheless the empirical literature on international student mobility devotes much less attention to the quality dimension. Few econometric studies have explicitly factored in quality differentials as a driver of international student flows. Most econometric studies have been concerned with the determinants and effects of flows of students from developing countries to industrialized countries (Naidoo, 2007; Bessey, 2007; McMahon, 1992; Agarwal and Winkler, 1985; Cummings, 1984; Lee and Tan, 1984). For the sending country, domestic opportunities 
for higher education and economic strength are factors commonly found to limit outward student mobility. For the host country, proximity to and close relations with the sending country (e.g. in the form of trade relations or former colonial links) are factors that commonly attract students from a particular sending country. Employment and permanent migration opportunities also influence a host country's appeal to foreign students.

A few studies based on survey data discuss the motivations of students to go abroad as well as the factors that encourage or inhibit this mobility. These studies generally confirm the importance of quality dimensions: differences in quality between a foreign degree and a domestic one are found to be one of the main motivations for students from developing countries to go abroad (Gordon and Jallade, 1996; Kemp et al., 1998; Aslanbeigui and Montecinos, 1998; Mazzarol and Soutar, 2000; Bourke, 2000, Szelényi, 2006).

As higher education quality differentials are likely to be much smaller among industrialized countries than between developing and industrialized countries, it remains to be seen whether the importance of the quality dimension remains valid for flows within Europe. However, very few econometric studies on student flows within developed countries include the quality dimension explicitly. Nevertheless, they do find evidence on the importance of traits of a country's higher education system that are possibly correlated to its quality, such as the staff-student ratio (Lee and Tan, 1984), educational opportunities (Cummings, 1984; Agarwal and Winkler, 1985; McMahon, 1992) and government spending on higher education (McMahon, 1992). A few studies factor in the quality dimension more explicitly. Although it is not the focus of their analysis, Thissen and Ederveen (2006) include a measure of quality among their list of determining factors in their study of intra-EU student mobility. They find that a positive quality differential significantly increases the enrolment of foreign students. Similarly, Rodríguez González et al. (2011) study the determinants of Erasmus student flows within Europe, and find that 
the number of top-ranked universities in a host country are a significant pull factor in the destination choice of Erasmus students. However, we believe that regular student mobility (i.e. students who enroll for a full programme abroad, as opposed to the Erasmus programme where students only spend one or two semesters abroad and remain enrolled in their home university) are driven to a greater extent by university quality, as the prestige of the foreign institution will be reflected in these students' final diploma. Erasmus students, by contrast, receive a diploma from their home university, and therefore their destination choice is arguably driven more by consumption motives, as illustrated by the significant attraction of countries with a warmer climate in Rodríguez González et al.’s model.

In conclusion, although the theoretical human capital literature and the qualitative evidence support the importance of quality considerations in the decision to pursue higher education abroad, the econometric analysis of the importance of quality among the factors driving international student mobility is less well-established, producing few robust findings as of yet - especially for more developed countries such as those in the European Higher Education Area.

\section{Methodology and data}

\section{Level of analysis}

To test whether university quality is one of the reasons for tertiary students to go abroad, ideally we should compare the quality of the institution the student attends abroad to the alternative options available to the student. This requires a large set of data covering a sufficient number of institutions in a sufficient number of countries. Lacking individual choice data, we take an alternative approach using macro-level data. The use of data at the 
national level has the substantial drawback that we no longer observe the individual institutions that foreign students attend, and therefore do not know whether a particular foreign student attends a high-quality or a low-quality institution. We only observe whether countries with better university systems on average attract significantly larger flows of incoming foreign students, ceteris paribus. However, a macro-level analysis remains interesting as it informs policy makers at the European level of the likely impact on the average quality of its higher education system should the ERA and Bologna process substantially increase aggregate student mobility in the future.

\section{The model}

We analyze the impact of higher education quality on student flows between European countries with a gravity model. Gravity models are regularly used in economics, most often to study bilateral trade flows, but also migration flows. Its basic specification is

$F_{i j}=\frac{S_{i}^{\alpha} \times S_{j}^{\beta}}{D_{i j}^{\gamma}} e^{\varepsilon_{i j}}(1)$

with $F_{i j}$ the flow of people from country $j$ to country $i, S_{i}$ and $S_{j}$ the respective sizes of countries $i$ and $j, D_{i j}$ the distance between these countries and $e^{\varepsilon_{i j}}$ the error term. For flows of people, the most often used measure of size is the relevant population, in casu the relevant student population. Big sending countries have more students to send out, whereas big host countries with more students have more infrastructure to absorb a larger number of incoming students. Distance is usually measured by the distance between both countries' capital cities, assuming that capital cities are often a large center of economic 
and intellectual life within a country. The closer the host country is to the sending country, the more students it is expected to attract. Not only are travel expenses lower with decreased distance, but also cultural and linguistic distance is smaller, thus lowering the adjustment costs a student experiences when moving to another country.

Gravity equations are often loglinearized in empirical applications, so the coefficients are interpreted as elasticities and extended to include other determining factors. Adding a quality measure of the host country's university system $\left(Q U A L_{i}\right)$ as well as other characteristics of the host country $\left(H C_{i}\right)$, the sending country $\left(S C_{j}\right)$, and characteristics on the relationship between the host and sender $\left(R_{i j}\right)$, yields our final model $^{2}$ :

$\log \left(F_{i j}\right)=\log (C)+\alpha \log \left(S_{i}\right)+\beta \log \left(S_{j}\right)-\gamma \log \left(D_{i j}\right)+\theta\left(R_{i j}\right)+\zeta\left(H C_{i}\right)+\eta S C_{j}+$

$\delta Q U A L_{i}+\varepsilon_{i j}$

Our main variable of interest will be the quality of the higher education system of the host country as a pull factor $\left(Q U A L_{i}\right)$. But in the analysis we will also look at the quality of the higher education of the sending country as a push factor and whether the quality differential or the gap in quality between the sending and the host country matters. To measure the quality of the higher education system we will use various indicators. The next sections detail the variables used.

\section{The data on flows of international students $\left(F_{i j}\right)$}

For flows of international students we use the joint Unesco Institute for Statistics (UIS)/OECD/Eurostat database on education (available through Eurostat). Countries

\footnotetext{
${ }^{2}$ All independent variables which are expressed as ratios are not expressed in logarithms.
} 
supply yearly data on the basis of commonly agreed definitions. Education is divided into levels according to the International Standard Classification of Education (ISCED). ${ }^{3}$

Our dataset contains 31 European countries $^{4}$ that all belong to the European Higher Education Area. We use a cross-section of the bilateral flows between these 31 countries for the year 2007 (the most recent year for which complete data are available), which leaves a maximum number of 931 observations. ${ }^{5}$

Students whose nationality differs from that of the country in which they enroll, are counted as foreign students ${ }^{6}$. For the analysis, we are interested in foreign students in tertiary education. The largest number of students is exchanged at the level of tertiary programmes with an academic orientation that gives access to advanced research programmes (ISCED level 5A). This group will be the focus of our analysis. But we also analyze students in the second stage of tertiary education, the PhD level (ISCED level 6). We compare the determinants of international mobility patterns across these two groups of tertiary students and expect the quality dimension to be stronger for the latter group ${ }^{7}$.

Data for the comparable population of tertiary students from the host country $\left(S_{i}\right)$ and the sender country $\left(S_{j}\right)$ are taken from Eurostat as well. A country's student population includes native students enrolled for a full academic year.

\footnotetext{
${ }^{3}$ More information on the ISCED classification can be found in Appendix A.

${ }^{4}$ Austria, Belgium, Bulgaria, Cyprus, the Czech Republic, Denmark, Estonia, Finland, France, Germany, Greece, Hungary, Iceland, Ireland, Italy, Liechtenstein, Latvia, Lithuania, Luxembourg, Malta, the Netherlands, Norway, Poland, Portugal, Romania, Slovenia, Slovakia, Spain, Sweden, Switzerland, and the United Kingdom. Neither Ireland nor Luxembourg report data on incoming foreign students, but will nevertheless be included in the sample as sending countries.

${ }^{5}$ Although the data are also available for an -albeit limited- range of years (2004-2007), the variation over time in this range is very limited. This strong persistency in the short run prohibits a useful panel data analysis.

${ }^{6}$ There are two issues with respect to this type of measurement. First, children of immigrants who were born and educated in a country but who nevertheless still retain their parents' foreign nationality, are counted as foreign students. Second, students who spend time abroad as part of an exchange program, such as the Erasmus programme, but remain enrolled at their home institution are not counted in this database.

${ }^{7}$ We exclude tertiary students at ISCED level 5B from the population, as these students are enrolled in more practically oriented courses and are therefore very different in profile than the other tertiary students. They are less likely to become internationally mobile, as reflected by the small volume of international students exchanged at this level.
} 
Figure 1 shows who are the major source and destination countries for international flows of tertiary students (ISCED 5A) within our sample. The UK is the largest net importer of European students, as it sent out only 8,400 students to the other countries in our sample in 2007 but received 118,000 in return. Germany is also a major destination for European students, with almost 85,000 foreign students in 2007. However, as Germany also sends out a large number of students to other European countries, it is a considerably smaller 'net importer' of students compared to the UK. Also Austria, Belgium, Denmark, the Netherlands, Sweden and Switzerland are net receiving countries. The major net exporters of students are Greece, Poland and Slovakia. While most eastern European countries are net senders, the Czech Republic and Hungary are net importers of students, mostly form other eastern European countries. They appear to serve as regional hubs of higher education in eastern Europe (Kondakci, 2011).

In general, small countries with a large neighboring country that shares their language and cultural characteristics have relatively high rates of outflow, particularly towards that 'big brother' country. Ireland, for example, has a high outflow rate towards the UK, or Iceland towards Denmark. Most other countries in the sample have in- and outflow rates ranging between $1 \%$ and $14 \%$ of their student population.

The picture is slightly different for graduate students (ISCED level 6). The number of observations for graduate students is slightly lower, as not all the countries in our sample report incoming foreign students at ISCED level 6. Germany, the Netherlands and Greece, for example, do not report incoming foreign students at this level. Inflows, outflows and net inflows are displayed in figure 2. Graduate students appear to be much more oriented towards the UK than undergraduates. Indeed, a Herfindahl index for comparable samples at the undergraduate and graduate level supports that the graduate market is much more concentrated in the UK than the undergraduate market (a Herfindahl index of 0.39 versus 0.29 , respectively). 


\section{Measuring the quality of countries' higher education}

To measure the aggregated quality of a country's higher education system, we use several different indicators. First, we measure the quality of a country's research through citations received to its scientific publications, as citations are widely regarded as an indicator of the quality of a publication. Most scientific publications are authored by researchers affiliated to universities. The quality of a country's scientific output should therefore closely reflect the quality of its university faculty more generally.

Students that have the opportunity to be close to top quality research may have an advantage over their peers that do not. As excellence in research contributes to a strong academic reputation, a degree from a country with a strong research reputation can be expected to have a higher market value than a degree from a less reputed country. Furthermore, it is not unlikely that excellence in research correlates with quality in tertiary education.

We use publication and citation data from the National Science Foundation's Science and Engineering Indicators $2004^{8}$. Citation data refer to citations made in 2003 to articles published in 1999, 2000 and 2001. To correct for the size of the country, we construct our quality measure as the share of a country's citations in total world citations, relative to the share of a country's publications in total world publications. If this ratio is above 1, then a country's research on average attracts more citations than the rest of the world's publications. We label this indicator 'relative impact'.

The indicator 'relative impact' has a number of drawbacks. For countries where a sizable part of academic research is done at research institutions, such as in France or

\footnotetext{
${ }^{8}$ Unfortunately, more recent versions of the NSF's Science and Engineering Indicators no longer include citation counts per country.
} 
Germany, this measure is probably less adequate for our purposes. Moreover, the use of citations reflects a specific perspective on research quality, namely through its visibility in the scientific community. It may therefore be too specific for prospective students who are evaluating their enhanced returns from studying in a higher quality country.

Our second measure of quality is based on the Academic Ranking of World Universities, also referred to as the Shanghai ranking. Compared to the 'relative impact' measure, the 'Shanghai Ranking' uses a broader set of indicators to measure the quality of universities. This ranking, compiled annually by Shanghai Jiao Tong University, ranks universities on the basis of alumni and staff winning Nobel prizes and Fields medals, the number of ISI highly cited researchers, the number of articles published in Nature and Science, the number of articles in the Science Citation Index Expanded and the Social Science Citation Index and the size of the university. Although the Shanghai ranking stirs heavy debates on its 'correctness' to measure quality, it attracts a lot of media-attention. It may therefore be one of the information sources prospective students are likely to use when they decide which university in which country to apply for.

To construct the 'Shanghai Ranking' indicator, we count the number of universities a country has in the top 200 of this ranking. This allows taking into account the 'quantity' of high-quality institutions present in a country. It may not be enough that a country has a reputation of research quality to attract large numbers of foreign students there also need to be enough available places at high quality institutions to make large incoming student flows possible. As a sensitivity check we also construct a measure that controls for the size of the host country directly. This size-corrected measure is a weighted sum of universities in the top 200 - with higher ranked universities receiving a larger weight - divided by the country's population (see Aghion et al. 2007).

Both measures, relative impact and Shanghai ranking, measure research quality, whereas undergraduate students probably care about teaching quality, which may not be 
correlated to research quality. Another well-known university ranking is the ranking of the Times Higher Education Supplement (THES). This ranking puts more emphasis on teaching quality. It is based on peer review, recruiter review, citations per academic staff, staff per students, and the proportion of international staff and students. Although the inclusion of international staff and students may introduce endogeneity with incoming student flows, its weight in the total ranking score is small (5\%) and thus contributes relatively little to a university's final ranking. As a third indicator, we therefore use the number of universities a country has in the THES ranking. This indicator should proxy better for the 'quantity' of high teaching quality institutions. As with the Shanghai ranking, we also compute a similar measure with the THES ranking that accounts for host country size as a sensitivity check.

The Shanghai and THES ranking differ somewhat, but not much. The UK clearly dominates both rankings, with 23 institutions in the Shanghai ranking and 32 in the THES ranking. Both rankings produce similar results with regard to the lowest scoring countries. The picture provided by the relative impact indicator is more nuanced. Denmark, Finland, Germany, the Netherlands, Sweden, Switzerland and the UK all have scores above 1. All three quality indicators are positively correlated, especially both ranking indicators which have a correlation of 0.98 (cf. table 1$)$.

\section{Other variables influencing international student mobility}

The distance between two countries $\left(D_{i j}\right)$ is measured by the distance between the capital cities of countries $i$ and $j$. Distance is calculated as the bird's eye distance between the capital cities of two countries. ${ }^{9}$ Two variables control for the relationship between the host country $i$ and the sending country $j\left(R_{i j}\right)$. A first dummy variable indicates whether

\footnotetext{
${ }^{9}$ See http://www.geobytes.com/CityDistanceTool.htm .
} 
the host and sender share a language. Migration costs are typically lower if a student migrates to a country where his/her official language is spoken. We therefore expect the size of the flow of tertiary students to be larger between countries with a shared language. A second dummy variable indicates whether the host and the sender share a border. Students from border regions may have to travel less far to attend a university across the border than within their home country. Moreover, neighboring countries often share a certain cultural and linguistic affinity that further lowers migration costs, thus increasing the flow of tertiary students between these countries. Both dummies are taken from CEPII's distances database ${ }^{10}$.

The vector $S C_{j}$ controls for sending country characteristics. Most of the literature on international student flows controls for educational opportunities at home to account for the possibility that tertiary students are forced to seek higher education abroad for lack of places in higher education institutions in their home country (Lee and Tan, 1984; Cummings, 1984; Agarwal and Winkler, 1985; McMahon, 1992; Naidoo, 2007). In line with this, we include a measure of the educational opportunities in the sending country, with educational opportunities measured as the proportion of students in tertiary education relative to the number of students in upper secondary education (ISCED level 3). For students in advanced research programmes (ISCED level 6) we measure educational opportunities as the proportion of students enrolled at this level relative to students in ISCED level 5A. We expect that countries with less educational opportunities send out a larger number of students to other countries. All student data are taken from Eurostat. There is little variation in the average educational opportunities of incoming foreign students' sending countries at the undergraduate level: in all countries in our sample, incoming students come from sending countries where on average $75 \%$ of students in

\footnotetext{
${ }^{10}$ The database is available on http://www.cepii.fr/anglaisgraph/bdd/distances.htm.
} 
upper secondary education are likely to pursue an undergraduate degree at the tertiary level (cf. table 2).

Two control variables account for the host country characteristics $H C_{i}$. First, we control for higher education expenditure per student. If more money is spent on higher education, more and better professors can be hired, better infrastructure can be built and more resources can be made available to students and researchers. Data on annual higher education expenditure per tertiary student (measured in full-time equivalents for ISCED levels 5 and 6) are taken from Eurostat for the year 2007, and are purchasing power standard-corrected, and therefore comparable between countries with different costs of living. The difference between western and eastern European countries in terms of spending is stark: whereas most western European countries spend between $€ 10,000$ and $€ 15,000$ per student in 2007 , most eastern European countries spent around $€ 3,000-€ 5,000$ (cf. table 2). Replacing higher education expenditure per student with a higher education expenditure compared to GDP per capita yields similar results. Second, we include the average amount of tuition in the host country as a measure for the cost of education. Standard economic theory assumes that the higher the cost of education in a particular country, the less the demand of foreign students for higher education in this country will be (Naidoo, 2007). However, in higher education tuition fees may act as a signal of quality. Higher tuition fees may therefore increase demand instead of reducing it. In many European countries, tuition fees are determined through public intervention and therefore do not necessarily reflect the full cost of providing higher education. The total cost of education for a student also includes, besides the tuition fees, the cost of books and materials and the cost of living, for which we have no information. As tuition fees nevertheless make up a sizeable chunk of the cost of higher education, we expect the average tuition fee in the host country to have a negative effect on the size of the incoming flow of foreign students. The data on tuition fees are taken from the OECD's 
Education at a Glance 2009 and reflect the tuition fees for the academic year 2006/2007. Average tuition fees vary strongly, with the UK charging the highest fee of almost $\$ 4,700$ and several countries, including Sweden, Denmark and the Czech Republic charging none. Unfortunately, for many countries information on tuition fees is not available, which leads to a significant loss of observations for host countries: 15 out of 31 countries do not report tuition fees. An alternative is to use the comparative price level index for education, available on Eurostat (reference year 2007, EU27 = 100). The advantage of the comparative price level index is that it is available for almost all countries in our sample, and arguably covers a wider range of education-related expenses. The disadvantage is that the 'education' category is too broad for the purpose of our study, and encompasses lower levels of education as well. Using the comparative price level index instead of tuition fees generates very similar results, but in our basic models we choose to retain tuition fees as it is a more precise measure that captures (part of the) cost at the tertiary level.

Last, regional dummies control for regional characteristics of the destination and source countries ${ }^{11}$. The base group is constituted by continental western Europe (France, Germany, Belgium, Luxembourg, the Netherlands and Austria). Additionally, we define four regions: Scandinavia, the Mediterranean, the New Member States and non-EU (Norway, Iceland, Switzerland and Liechtenstein). In addition to these regional dummies, we include a dummy for the English-speaking countries in the sample (Ireland and the United Kingdom). As English has acquired the status of lingua franca in science over the past century, these countries may be especially appealing for international students. Second, higher education in the Anglo-Saxon countries has always had more affinity to the US system than with the continental European one. The English dummy should control for this difference in educational culture.

\footnotetext{
${ }^{11}$ Ideally we would include country dummies in the model, as these are better suited to control for unobserved host and sender characteristics. However, the limited number of observations precludes us from including country dummies.
} 


\section{Results}

\section{Basic results}

Table 3 reports the regression results of a series of basic gravity models for international student flows at ISCED level 5A. Robust t-statistics are reported between brackets. As a first benchmark, the results from a simple gravity model are reported with size, distance, a border and language dummy, and regional dummies (column 1). All the variables have the expected signs and most are highly significant, with the exception of the language dummy. Apparently language differences are not a deterrent for international students, probably because of the widespread adoption of English in higher education. Note that several regional dummies are highly significant. This suggests that there are indeed regional characteristics that have an impact on the size and direction of student flows. The Mediterranean countries and the new EU member states receive less international students than the base group, northwestern Europe. By contrast, the English speaking countries receive significantly more students than the base group.

In the second specification (column 2), additional host and sender characteristics are added. Higher education expenditure in the host country has a positive effect on the size of incoming student flows, although the coefficient is only significant at the $10 \%$ level. The coefficient for tuition fees is negative and highly significant. Educational opportunities in the sending country have no significant impact, which can probably be explained by the lack of variation in this variable.

We now turn to our main focus of interest, namely the impact of quality on international student flows. Column 3 includes the 'relative impact' measure for research quality of the host country. 'Relative impact' has a strongly positive and significant impact on student flows: a $10 \%$ increase in this indicator would on average lead to a $26 \%$ 
increase in the number of incoming students. Column 4 includes the university counts in the top 200 of the Shanghai ranking. The Shanghai ranking indicator also has a positive and significant effect: ceteris paribus, an additional institution in the top 200 increases the number of incoming students by approximately $11 \%$. When the Shanghai ranking top 200 indicator is included, the English speaking host country dummy loses its significance, suggesting that the popularity of the Anglosaxon countries among foreign students is explain to a large extent by their high number of high quality institutions (especially in the case of the UK). Finally, column 5 includes the university counts in the THES ranking, as a closer measure for teaching quality. Contrary to the previous two quality measures, the coefficient for the THES ranking is not significantly different from zero. As the THES ranking is more skewed towards British and Irish universities than the Shanghai ranking, we expect this variable to be more affected by multicollinearity with the English speaking host country dummy. Omitting the English speaking host dummy indeed makes the THES ranking country positive and significant (cf. appendix table B1, column 6).

Overall, the results are very favorable for a significant and sizeable impact of the quality of research of the destination country on flows of incoming tertiary students.

\section{Robustness of the results with respect to the quality indicators}

We check the robustness of our results with alternative constructions of the quality indicators. The results are reported in appendix table B1. When we substitute our relative impact factor for the more common measure of average citations per publication in a country, we still find a significantly positive coefficient, but the size of the coefficient is smaller (column 1). Including the number of institutes in the top 500 of the Shanghai ranking, rather than the top 200 , i.e. lowering our quality benchmark, the coefficient is still positive and significant but smaller (column 2). Top quality therefore seems a 
stronger attractor than average quality. Although our specification already includes a correction for size through $\mathrm{S}_{\mathrm{i}}$, we also include a size-corrected measure for the Shanghai ranking as constructed by Aghion et al. (2007). The coefficient remains positive and significant (column 3). The same indicator constructed with the THES ranking turns out negative and significant (column 4), but again the strong UK-effect appears to be behind this result (column 5).

Overall, our result that the quality of a host country's higher education system helps explain the size and direction of student flows at ISCED level 5A seems fairly robust to variation in construction of the quality indicators. The insignificant or negative coefficients obtained with the Times Higher Education Ranking are mainly attributable to the skew in this indicator in favor of the UK.

\section{Push versus Pull and Relative versus Absolute quality}

Besides operating as a pull factor at the host country level, we also test whether quality operates as a push factor at the level of the sending country. More specifically, we would expect that sending country quality will have a negative effect: students have less incentive to seek higher education abroad when their home country offers sufficient highquality options. The data, however, do not confirm this: sending country quality is not significant for any of the quality indicators we use, suggesting that university quality operates mainly as a pull factor at the host country level rather than as a push factor from the sending countries, at least for our sample of European countries (Appendix table B2).

A related question is whether it is the difference in quality between the host and the home country that drives international student flows. In table 4 , we estimate three gravity models with all country characteristics, including our three measures of quality, in 
relative terms, i.e. host versus sender level ${ }^{12}$. The relative quality indicators are not significantly different from zero, with the exception of the relative Shanghai ranking count which remains significant at the $10 \%$ level. Although its coefficient is positive, as expected, it is small in size. For example, if the number of top 200 institutions in the host country doubles with respect to the number in the sending country (a jump in the relative quality indicator from 1 to 2), then the student flow from sender to host would increase by approximately $3 \%$.

\footnotetext{
${ }^{12}$ When the sending country value for a specific variable, and thus the denominator, is zero, we set the value of the relative variable to zero.
} 


\section{Advanced research students}

Lastly, we check the effect of quality for students in advanced research studies (ISCED level 6). Particularly, as this is a bigger investment decision, we would expect these students to be more sensitive to the research quality of their host institutions. Table 5 displays the results for the basic gravity models at ISCED level 6 in the first three columns, and, as a comparison, the same basic gravity models for the comparable set of countries at the ISCED level 5A in the last three columns. Surprisingly, the quality indicators are a lot less significant at ISCED level 6: only the ranking indicators are significant at the $10 \%$ level. In the first specification, with the relative impact indicator, there is a strong and highly significant English-speaking host country effect. In appendix table B3 we check whether the presence of this English-speaking host dummy is what makes the quality indicators insignificant. Omitting this dummy indeed makes all three quality indicators highly significant for ISCED 6. This high correlation between the quality effect and the UK/English-speaking host dummy effect is reminiscent of the observation that the flow of students at ISCED6 is heavily concentrated on the UK as destination and that the quality of $\mathrm{PhD}$ programs in the $\mathrm{UK}$ is high relative to equivalent programs in other countries of our sample.

Also contrary to ISCED 5A students, lack of educational opportunities at home seems to significantly drive ISCED 6 student flows: an increase in available places in the sending country of 1 percentage point would on average lead to a decrease of the number of outgoing students by almost $16 \%$. Availability of educational opportunities for $\mathrm{PhD}$ students therefore seem to be a significant push factor for explaining international mobility of PhD students in Europe. 


\section{Conclusion}

Although the existing literature on international student flows mentions the importance of quality differentials in the decision to study abroad, few empirical studies explicitly include a measure of university quality. We use an extended gravity model to assess to what extent quality of higher education helps explain flows of international students between countries.

We find that quality of the host country, measured by the relative impact of a country's publications and especially the number of universities a country has in the top 200 of the Shanghai ranking, is indeed a factor that significantly determines the size and direction of student flows in a sample of 31 European countries. Using the number of institutes in the Times Higher Education Ranking as an indicator for quality yields no significant results. This is mainly attributable to its skew in favor of the UK. For the mobility patterns of students in advanced research studies (e.g. doctoral students), the quality effect is heavily correlated with the 'UK-effect', as the UK is the dominant destination country. Educational opportunities (or lack thereof) are an important factor driving outward flows of $\mathrm{PhD}$ students.

From a European policy perspective, our findings imply that removing barriers to student mobility in Europe could indeed have a positive effect on improving university quality as international flows of tertiary students are significantly guided by quality considerations.

This research suffers from the drawbacks of conducting a macro-level analysis of a multi-faceted phenomenon. Heterogeneity among institutions, fields and regions is concealed by the use of national data. Our findings should therefore be seen as a part of bigger research agenda. Much as we would like to conclude that student mobility is guided by quality considerations, we can only conclude that at the macro-level, several 
different quality indicators appear to help explain the size and direction of student flows. To confirm the former, bolder conclusion, additional research at the micro- and mesolevel should be done. For this, comparable data for European universities of quality indicators as well as student in-and out-flows would be most welcome. 


\section{Acknowledgements}

Financial support from the Belgian Federal Government (PAI 06/09) and the Fund for Scientific Research (FWO) is gratefully acknowledged. The views expressed in this paper do not necessarily reflect the views of the Katholieke Universiteit Leuven, Bruegel or CEPR. We wish to thank the participants of the MSI Brown Bag seminar series, the IAP meeting 2009, the DRUID Summer Conference 2009, the SCIFI-GLOW research meeting 2009, the EEA Conference 2009 and the EARIE Conference 2009 for their helpful suggestions and comments. All errors remain for the authors. 


\section{Appendix A - International Standard Classification of Education (ISCED 1997)}

The International Standard Classification of Education (ISCED) was designed by UNESCO in the early 1970's to serve 'as an instrument suitable for assembling, compiling and presenting statistics of education both within individual countries and internationally'. The present classification, now known as ISCED 1997, was approved by the UNESCO General Conference in November 1997.

\section{Level 5: First stage of tertiary education (not leading directly to an advanced research qualification)}

This level consists of tertiary programmes having an educational content more advanced than those offered at levels 3 (upper secondary education) and 4 (post-secondary nontertiary education). Entry to these programmes normally requires the successful completion of ISCED level 3A or 3B or a similar qualification at ISCED level 4A.

There is a distinction between the programmes which are theoretically based/research preparatory (history, philosophy, mathematics, etc.) or giving access to professions with high skills requirements (e.g. medicine, dentistry, architecture, etc.) (level 5A), and those programmes which are practical/technical/occupationally specific (level 5B).

ISCED level 5A programmes must satisfy a sufficient number of the following criteria:

(i) they have a minimum cumulative theoretical duration (at tertiary) of three years' full-time equivalent, although typically they are of 4 or more years. If a degree has 3 years' full-time equivalent duration, it is usually preceded by at least 13 years of previous schooling.

(ii) they typically require that the faculty have advanced research credentials;

(iii) they may involve completion of a research project or thesis; 
(iv) they provide the level of education required for entry into a profession with high skills requirements or an advanced research programme.

Qualifications in category 5B are typically shorter than those in 5A and focus on occupationally specific skills geared for entry into the labour market, although some theoretical foundations may be covered in the respective programme.

\section{Level 6 - Second stage of tertiary education (leading to an advanced research qualification)}

This level is reserved for tertiary programmes which lead to the award of an advanced research qualification. The programmes are therefore devoted to advanced study and original research and are not based on course-work only. It typically requires the submission of a thesis or dissertation of publishable quality which is the product of original research and represents a significant contribution to knowledge. It prepares graduates for faculty posts in institutions offering ISCED 5A programmes, as well as research posts in government, industry, etc. 
Appendix B - Robustness checks

Table B1

Robustness checks - alternative quality indicators

\begin{tabular}{|c|c|c|c|c|c|c|}
\hline & $(1)$ & (2) & (3) & (4) & $(5)$ & (6) \\
\hline VARIABLES & lintstud5a & lintstud5a & lintstud5a & lintstud5a & lintstud5a & lintstud5a \\
\hline student population - host & $\begin{array}{l}0.674 * * * \\
(0.0863)\end{array}$ & $\begin{array}{l}-0.410 * * \\
(0.167)\end{array}$ & $\begin{array}{l}0.706^{* * * *} \\
(0.0899)\end{array}$ & $\begin{array}{l}0.726 * * * \\
(0.0827)\end{array}$ & $\begin{array}{l}0.943 * * * \\
(0.0760)\end{array}$ & $\begin{array}{l}0.719 * * * \\
(0.0851)\end{array}$ \\
\hline student population - sender & $\begin{array}{l}0.710 * * * \\
(0.0449)\end{array}$ & $\begin{array}{l}0.714 * * * \\
(0.0424)\end{array}$ & $\begin{array}{l}0.710 * * * \\
(0.0454)\end{array}$ & $\begin{array}{l}0.710 * * * \\
(0.0448)\end{array}$ & $\begin{array}{l}0.712 * * * \\
(0.0466)\end{array}$ & $\begin{array}{l}0.709 * * * \\
(0.0455)\end{array}$ \\
\hline distance & $\begin{array}{l}-0.685 * * * \\
(0.135)\end{array}$ & $\begin{array}{l}-0.679 * * * \\
(0.139)\end{array}$ & $\begin{array}{l}-0.726 * * * \\
(0.135)\end{array}$ & $\begin{array}{l}-0.746 * * * \\
(0.135)\end{array}$ & $\begin{array}{l}-0.649 * * * \\
(0.139)\end{array}$ & $\begin{array}{l}-0.722 * * * \\
(0.135)\end{array}$ \\
\hline shared border & $\begin{array}{l}0.948 * * * \\
(0.323)\end{array}$ & $\begin{array}{l}0.896^{* * *} \\
(0.319)\end{array}$ & $\begin{array}{l}0.904 * * * \\
(0.324)\end{array}$ & $\begin{array}{l}0.835 * * \\
(0.328)\end{array}$ & $\begin{array}{l}0.923 \text { *** } \\
(0.328)\end{array}$ & $\begin{array}{l}0.913 * * * \\
(0.323)\end{array}$ \\
\hline shared language & $\begin{array}{l}0.595 \\
(0.429)\end{array}$ & $\begin{array}{l}0.531 \\
(0.416)\end{array}$ & $\begin{array}{l}0.584 \\
(0.433)\end{array}$ & $\begin{array}{l}0.568 \\
(0.423)\end{array}$ & $\begin{array}{l}0.627 \\
(0.430)\end{array}$ & $\begin{array}{l}0.614 \\
(0.432)\end{array}$ \\
\hline higher education expenditure & $\begin{array}{l}1.024 * * \\
(0.414)\end{array}$ & $\begin{array}{l}3.477 * * * \\
(0.484)\end{array}$ & $\begin{array}{l}0.169 \\
(0.529)\end{array}$ & $\begin{array}{l}1.102 * * \\
(0.452)\end{array}$ & $\begin{array}{l}0.463 \\
(0.466)\end{array}$ & $\begin{array}{l}0.699 * \\
(0.424)\end{array}$ \\
\hline tuition fee & $\begin{array}{l}-0.194 * * * \\
(0.0505)\end{array}$ & $\begin{array}{l}-0.323 * * * \\
(0.0536)\end{array}$ & $\begin{array}{l}-0.190 * * * \\
(0.0517)\end{array}$ & $\begin{array}{l}-0.166^{* * *} \\
(0.0494)\end{array}$ & $\begin{array}{l}-0.120 * * \\
(0.0487)\end{array}$ & $\begin{array}{l}-0.178 * * * \\
(0.0503)\end{array}$ \\
\hline educational opportunities & $\begin{array}{l}-0.419 \\
(0.300)\end{array}$ & $\begin{array}{l}-0.450 \\
(0.287)\end{array}$ & $\begin{array}{l}-0.428 \\
(0.303)\end{array}$ & $\begin{array}{l}-0.433 \\
(0.303)\end{array}$ & $\begin{array}{l}-0.400 \\
(0.316)\end{array}$ & $\begin{array}{l}-0.418 \\
(0.304)\end{array}$ \\
\hline citations/publication & $\begin{array}{l}1.215^{* * * *} \\
(0.373)\end{array}$ & & & & & \\
\hline $\operatorname{sr} 500$ & & $\begin{array}{l}0.180 * * * \\
(0.0228)\end{array}$ & & & & \\
\hline SR indicator & & & $\begin{array}{l}0.425^{*} \\
(0.217)\end{array}$ & & & \\
\hline THES indicator & & & & $\begin{array}{l}-0.450 * * * \\
(0.169)\end{array}$ & $\begin{array}{l}0.484 * * * \\
(0.150)\end{array}$ & \\
\hline THES ranking count & & & & & & $\begin{array}{l}0.0679 * * * \\
(0.0110)\end{array}$ \\
\hline host - Scandinavia & $\begin{array}{l}-2.347 * * * \\
(0.519)\end{array}$ & $\begin{array}{l}-3.057 * * * \\
(0.518)\end{array}$ & $\begin{array}{l}-2.445^{* * *} \\
(0.616)\end{array}$ & $\begin{array}{l}-1.777 * * * \\
(0.494)\end{array}$ & $\begin{array}{l}-1.606 * * * \\
(0.497)\end{array}$ & $\begin{array}{l}-1.790 * * * \\
(0.495)\end{array}$ \\
\hline host - Mediterranean & $\begin{array}{l}-0.0573 \\
(0.312)\end{array}$ & $\begin{array}{l}1.635 \text { *** } \\
(0.354)\end{array}$ & $\begin{array}{l}-0.742 * * * \\
(0.248)\end{array}$ & $\begin{array}{l}-0.991 * * * \\
(0.248)\end{array}$ & $\begin{array}{l}-0.865 * * * \\
(0.247)\end{array}$ & $\begin{array}{l}-0.448 * \\
(0.260)\end{array}$ \\
\hline host - new member state & $\begin{array}{l}-1.960 * * * \\
(0.521)\end{array}$ & $\begin{array}{l}-1.279 * * * \\
(0.455)\end{array}$ & $\begin{array}{l}-3.391 * * * \\
(0.478)\end{array}$ & $\begin{array}{l}-3.258 * * * \\
(0.440)\end{array}$ & $\begin{array}{l}-2.569 * * * \\
(0.437)\end{array}$ & $\begin{array}{l}-2.812^{* * *} \\
(0.427)\end{array}$ \\
\hline host - non EU & $\begin{array}{l}2.444 * * * \\
(0.535)\end{array}$ & $\begin{array}{l}2.823 * * * \\
(0.504)\end{array}$ & $\begin{array}{l}2.176^{* * * *} \\
(0.543)\end{array}$ & $\begin{array}{l}1.356^{* * * *} \\
(0.514)\end{array}$ & $\begin{array}{l}2.014 * * * \\
(0.532)\end{array}$ & $\begin{array}{l}1.978 * * * \\
(0.496)\end{array}$ \\
\hline host - English speaking & $\begin{array}{l}1.766^{* * *} \\
(0.280)\end{array}$ & $\begin{array}{l}-2.063 * * * \\
(0.554)\end{array}$ & $\begin{array}{l}1.610 * * * \\
(0.286)\end{array}$ & $\begin{array}{l}2.399 * * * \\
(0.348)\end{array}$ & & \\
\hline sender - Scandinavia & $\begin{array}{l}0.397 * \\
(0.213)\end{array}$ & $\begin{array}{l}0.390 * \\
(0.204)\end{array}$ & $\begin{array}{l}0.413 * \\
(0.214)\end{array}$ & $\begin{array}{l}0.415 * \\
(0.214)\end{array}$ & $\begin{array}{l}0.370 * \\
(0.223)\end{array}$ & $\begin{array}{l}0.412 * \\
(0.215)\end{array}$ \\
\hline sender - Mediterranean & $\begin{array}{l}0.513 * \\
(0.281)\end{array}$ & $\begin{array}{l}0.509 * \\
(0.271)\end{array}$ & $\begin{array}{l}0.543 * \\
(0.279)\end{array}$ & $\begin{array}{l}0.552 * * \\
(0.278)\end{array}$ & $\begin{array}{l}0.468 \\
(0.285)\end{array}$ & $\begin{array}{l}0.539 * \\
(0.281)\end{array}$ \\
\hline sender - new member state & $\begin{array}{l}0.396 * * \\
(0.196)\end{array}$ & $\begin{array}{l}0.389 * * \\
(0.187)\end{array}$ & $\begin{array}{l}0.407 * * \\
(0.195)\end{array}$ & $\begin{array}{l}0.405 * * \\
(0.196)\end{array}$ & $\begin{array}{l}0.368 * \\
(0.202)\end{array}$ & $\begin{array}{l}0.407 * * \\
(0.196)\end{array}$ \\
\hline sender - non EU & $\begin{array}{l}0.378 \\
(0.239)\end{array}$ & $\begin{array}{l}0.382 * \\
(0.228)\end{array}$ & $\begin{array}{l}0.378 \\
(0.242)\end{array}$ & $\begin{array}{l}0.379 \\
(0.243)\end{array}$ & $\begin{array}{l}0.372 \\
(0.251)\end{array}$ & $\begin{array}{l}0.376 \\
(0.242)\end{array}$ \\
\hline sender - English speaking & 0.0493 & 0.0404 & 0.0545 & 0.0489 & 0.00160 & 0.0516 \\
\hline
\end{tabular}




\begin{tabular}{|c|c|c|c|c|c|c|}
\hline & $(0.211)$ & $(0.205)$ & $(0.208)$ & $(0.210)$ & $(0.230)$ & $(0.211)$ \\
\hline Constant & $\begin{array}{l}-18.39 * * * \\
(4.269)\end{array}$ & $\begin{array}{l}-26.32 * * * \\
(4.265)\end{array}$ & $\begin{array}{l}-8.173 \\
(5.540)\end{array}$ & $\begin{array}{l}-16.64 * * * \\
(4.485)\end{array}$ & $\begin{array}{l}-15.06 * * * \\
(4.645)\end{array}$ & $\begin{array}{l}-13.61 * * * \\
(4.387)\end{array}$ \\
\hline Observations & 435 & 435 & 435 & 435 & 435 & 435 \\
\hline R-squared & 0.777 & 0.794 & 0.774 & 0.775 & 0.758 & 0.772 \\
\hline
\end{tabular}


Table B2

Robustness checks - sending country quality

\begin{tabular}{|c|c|c|c|}
\hline & (1) & (2) & (3) \\
\hline VARIABLES & lintstud5a & lintstud5a & lintstud5a \\
\hline \multirow[t]{2}{*}{ student population - host } & $0.682 * * *$ & $0.560 * * *$ & $0.746^{* * *}$ \\
\hline & $(0.0840)$ & $(0.109)$ & $(0.0869)$ \\
\hline \multirow[t]{2}{*}{ student population - sender } & $0.596 * * *$ & $0.693 * * *$ & $0.711^{* * *}$ \\
\hline & $(0.0591)$ & $(0.0557)$ & $(0.0526)$ \\
\hline \multirow[t]{2}{*}{ distance } & $-0.714 * * *$ & $-0.711 * * *$ & $-0.726 * * *$ \\
\hline & $(0.130)$ & $(0.136)$ & $(0.135)$ \\
\hline \multirow[t]{2}{*}{ shared border } & $1.106^{* * *}$ & $0.933 * * *$ & $0.891 * * *$ \\
\hline & $(0.299)$ & $(0.323)$ & $(0.326)$ \\
\hline \multirow[t]{2}{*}{ shared language } & 0.0440 & 0.628 & 0.596 \\
\hline & $(0.334)$ & $(0.432)$ & $(0.428)$ \\
\hline \multirow[t]{2}{*}{ higher education expenditure } & $0.853 * *$ & $1.127 * * *$ & $0.749 *$ \\
\hline & $(0.419)$ & $(0.420)$ & $(0.430)$ \\
\hline \multirow[t]{2}{*}{ tuition fee } & $-0.221 * * *$ & $-0.203 * * *$ & $-0.172 * * *$ \\
\hline & $(0.0500)$ & $(0.0519)$ & $(0.0507)$ \\
\hline \multirow[t]{2}{*}{ educational opportunities } & -0.357 & -0.342 & -0.431 \\
\hline & $(0.275)$ & $(0.329)$ & $(0.330)$ \\
\hline \multirow[t]{2}{*}{ relative impact } & $2.093 * * *$ & & \\
\hline & $(0.780)$ & & \\
\hline \multirow[t]{2}{*}{ relative impact - sender } & -0.783 & & \\
\hline & $(0.488)$ & & \\
\hline \multirow[t]{2}{*}{ Shanghai ranking count } & & $0.110 * * *$ & \\
\hline & & $(0.0357)$ & \\
\hline \multirow[t]{2}{*}{ Shanghai ranking count - sender } & & 0.0115 & \\
\hline & & $(0.0168)$ & \\
\hline \multirow[t]{2}{*}{ THES ranking count } & & & 0.0227 \\
\hline & & & $(0.0274)$ \\
\hline \multirow[t]{2}{*}{ THES ranking count - sender } & & & -0.000959 \\
\hline & & & $(0.0127)$ \\
\hline \multirow[t]{2}{*}{ host - Scandinavia } & $-2.584 * * *$ & $-2.008 * * *$ & $-1.837 * * *$ \\
\hline & $(0.504)$ & $(0.502)$ & $(0.495)$ \\
\hline \multirow[t]{2}{*}{ host - Mediterranean } & -0.246 & -0.0913 & $-0.654 * *$ \\
\hline & $(0.310)$ & $(0.330)$ & $(0.282)$ \\
\hline \multirow[t]{2}{*}{ host - new member state } & $-2.472 * * *$ & $-2.615 * * *$ & $-2.969 * * *$ \\
\hline & $(0.510)$ & $(0.440)$ & $(0.432)$ \\
\hline \multirow[t]{2}{*}{ host - non EU } & $2.587 * * *$ & $2.117 * * *$ & $1.864 * * *$ \\
\hline & $(0.540)$ & $(0.505)$ & $(0.505)$ \\
\hline \multirow[t]{2}{*}{ host - English speaking } & $1.765 * * *$ & 0.125 & $1.224^{*}$ \\
\hline & $(0.272)$ & $(0.571)$ & $(0.684)$ \\
\hline \multirow[t]{2}{*}{ sender - Scandinavia } & 0.123 & $0.439 * *$ & $0.410 *$ \\
\hline & $(0.207)$ & $(0.215)$ & $(0.215)$ \\
\hline \multirow[t]{2}{*}{ sender - Mediterranean } & 0.195 & $0.570 * *$ & $0.538 *$ \\
\hline & $(0.285)$ & $(0.283)$ & $(0.281)$ \\
\hline \multirow[t]{2}{*}{ sender - new member state } & -0.200 & $0.450 * *$ & $0.403 * *$ \\
\hline & $(0.315)$ & $(0.203)$ & $(0.199)$ \\
\hline \multirow[t]{2}{*}{ sender - non EU } & 0.367 & 0.370 & 0.378 \\
\hline & $(0.247)$ & $(0.240)$ & $(0.243)$ \\
\hline sender - English speaking & -0.0932 & -0.00367 & 0.0630 \\
\hline
\end{tabular}




\begin{tabular}{llll} 
& $(0.205)$ & $(0.233)$ & $(0.261)$ \\
Constant & $-13.65^{* * *}$ & $-15.61^{* * * *}$ & $-14.19^{* * *}$ \\
& $(4.649)$ & $(4.264)$ & $(4.464)$ \\
& & & \\
Observations & 405 & 435 & 435 \\
R-squared & 0.758 & 0.776 & 0.773 \\
\hline Robust standard errors in parentheses:*** $<<0.01, * * 0<0.05, * 00.1$
\end{tabular}

Robust standard errors in parentheses; *** $\mathrm{p}<0.01,{ }^{* *} \mathrm{p}<0.05,{ }^{*} \mathrm{p}<0.1$ 
Table B3

Robustness checks - additional ISCED level 6 regressions

\begin{tabular}{|c|c|c|c|c|c|c|}
\hline & (1) & (2) & (3) & (4) & (5) & (6) \\
\hline VARIABLES & lintstud6 & lintstud6 & lintstud6 & lintstud5a & lintstud5a & lintstud5a \\
\hline \multirow[t]{2}{*}{ student population (graduate) - host } & $0.977 * * *$ & $0.798 * * *$ & $0.845 * * *$ & $0.738 * * *$ & $0.537 * * *$ & $0.712 * * *$ \\
\hline & $(0.0751)$ & $(0.0838)$ & $(0.0802)$ & $(0.0882)$ & $(0.0996)$ & $(0.0875)$ \\
\hline \multirow{2}{*}{$\begin{array}{l}\text { student population } \\
\text { sender }\end{array}$} & $0.551 * * *$ & $0.546 * * *$ & $0.545 * * *$ & $0.702 * * *$ & $0.695 * * *$ & $0.694 * * *$ \\
\hline & $(0.0400)$ & $(0.0393)$ & $(0.0393)$ & $(0.0489)$ & $(0.0486)$ & $(0.0491)$ \\
\hline \multirow[t]{3}{*}{ distance } & - & $-0.521 * * *$ & $-0.547 * * *$ & - & - & $-0.812 * * *$ \\
\hline & $0.453 * * *$ & & & $0.626 * * *$ & $0.801 * * *$ & \\
\hline & $(0.138)$ & $(0.131)$ & $(0.129)$ & $(0.150)$ & $(0.141)$ & $(0.140)$ \\
\hline \multirow[t]{2}{*}{ shared border } & $1.092 * * *$ & $1.106 * * *$ & $1.083 * * *$ & $0.916 * *$ & $0.824 * *$ & $0.792 * *$ \\
\hline & $(0.312)$ & $(0.301)$ & $(0.297)$ & $(0.377)$ & $(0.363)$ & $(0.363)$ \\
\hline \multirow[t]{2}{*}{ shared language } & 0.0922 & 0.116 & 0.114 & 0.547 & 0.632 & 0.641 \\
\hline & $(0.308)$ & $(0.303)$ & $(0.299)$ & $(0.473)$ & $(0.472)$ & $(0.470)$ \\
\hline \multirow[t]{2}{*}{ higher education expenditure } & $0.906^{*}$ & $0.889 * *$ & 0.606 & $1.852 * * *$ & $1.270 * * *$ & $0.800 *$ \\
\hline & $(0.468)$ & $(0.441)$ & $(0.443)$ & $(0.452)$ & $(0.429)$ & $(0.443)$ \\
\hline \multirow[t]{3}{*}{ tuition fee } & $0.137 * * *$ & 0.0618 & 0.0720 & - & - & $-0.181 * * *$ \\
\hline & & & & $0.151 * * *$ & $0.207 * * *$ & \\
\hline & $(0.0485)$ & $(0.0525)$ & $(0.0518)$ & $(0.0504)$ & $(0.0527)$ & $(0.0517)$ \\
\hline \multirow[t]{3}{*}{ educational opportunities (graduate) } & - & $-16.04 * * *$ & $-15.88 * * *$ & -0.437 & -0.462 & -0.457 \\
\hline & $16.16 * * *$ & & & & & \\
\hline & $(2.976)$ & $(2.927)$ & $(2.937)$ & $(0.323)$ & $(0.314)$ & $(0.319)$ \\
\hline \multirow[t]{2}{*}{ relative impact } & $2.328 * *$ & & & $5.917 * * *$ & & \\
\hline & $(0.980)$ & & & (1.187) & & \\
\hline \multirow[t]{2}{*}{ Shanghai ranking count } & & $0.0751 * * *$ & & & $0.119 * * *$ & \\
\hline & & $(0.0146)$ & & & $(0.0177)$ & \\
\hline \multirow[t]{2}{*}{ THES ranking count } & & & $0.0516 * * *$ & & & $0.0684 * * *$ \\
\hline & & & $(0.0102)$ & & & $(0.0113)$ \\
\hline \multirow[t]{3}{*}{ host - Scandinavia } & 0.733 & 0.592 & 0.709 & - & - & $-1.913 * * *$ \\
\hline & & & & $2.859 * * *$ & $2.154 * * *$ & \\
\hline & $(0.524)$ & $(0.497)$ & $(0.494)$ & $(0.573)$ & $(0.514)$ & $(0.507)$ \\
\hline \multirow[t]{2}{*}{ host - Mediterranean } & $-0.724 * *$ & $-0.567 * *$ & $-0.668 * *$ & 0.273 & -0.0844 & $-0.483 *$ \\
\hline & $(0.333)$ & $(0.274)$ & $(0.274)$ & $(0.342)$ & $(0.289)$ & $(0.269)$ \\
\hline \multirow[t]{3}{*}{ host - new member state } & 0.240 & $-0.757 *$ & $-0.909 * *$ & -0.192 & - & $-2.847 * * *$ \\
\hline & & & & & $2.622 * * *$ & \\
\hline & $(0.605)$ & $(0.431)$ & $(0.434)$ & $(0.650)$ & $(0.429)$ & $(0.436)$ \\
\hline \multirow[t]{2}{*}{ host - non EU } & -0.0103 & -0.0513 & -0.112 & $2.989 * * *$ & $2.193 * * *$ & $2.035 * * *$ \\
\hline & $(0.521)$ & $(0.467)$ & $(0.467)$ & $(0.585)$ & $(0.510)$ & $(0.509)$ \\
\hline \multirow[t]{2}{*}{ sender - Scandinavia } & -0.253 & -0.212 & -0.200 & $0.473 * *$ & $0.573 * *$ & $0.575 * *$ \\
\hline & $(0.215)$ & $(0.206)$ & $(0.207)$ & $(0.240)$ & $(0.230)$ & $(0.234)$ \\
\hline \multirow[t]{2}{*}{ sender - Mediterranean } & $0.617 * * *$ & $0.682 * * *$ & $0.702 * * *$ & $0.585^{*}$ & $0.748 * *$ & $0.752 * *$ \\
\hline & $(0.226)$ & $(0.224)$ & $(0.224)$ & $(0.309)$ & $(0.305)$ & $(0.307)$ \\
\hline \multirow[t]{2}{*}{ sender - new member state } & -0.0172 & 0.0206 & 0.0296 & $0.494 * *$ & $0.580 * * *$ & $0.579 * * *$ \\
\hline & $(0.170)$ & $(0.167)$ & $(0.166)$ & $(0.220)$ & $(0.212)$ & $(0.214)$ \\
\hline \multirow[t]{2}{*}{ sender - non EU } & 0.0268 & 0.0292 & 0.0306 & 0.426 & $0.432 *$ & $0.432 *$ \\
\hline & $(0.249)$ & $(0.237)$ & $(0.238)$ & $(0.265)$ & $(0.255)$ & $(0.260)$ \\
\hline \multirow[t]{2}{*}{ sender - English speaking } & $-0.358 *$ & -0.302 & -0.293 & 0.150 & 0.249 & 0.244 \\
\hline & $(0.202)$ & $(0.184)$ & $(0.184)$ & $(0.261)$ & $(0.226)$ & $(0.230)$ \\
\hline
\end{tabular}




\begin{tabular}{lllllll} 
Constant & - & $-14.57^{* * * *}$ & $-12.19^{* * * *}$ & - & - & $-13.68 * * *$ \\
& $19.15^{* * *}$ & & & $30.47 * * *$ & $15.97 * * *$ & \\
& $(4.826)$ & $(4.245)$ & $(4.279)$ & $(4.869)$ & $(4.419)$ & $(4.581)$ \\
& & & & & & \\
Observations & 392 & 392 & 392 & 392 & 392 & 392 \\
R-squared & 0.757 & 0.767 & 0.767 & 0.758 & 0.770 & 0.764 \\
\hline Robust standard errors in parentheses:*** $<0.01 * * \mathrm{p}<0.05 * \mathrm{p}<0.1$ & & & &
\end{tabular}




\section{References}

Abbott, W. and Schmid, C. F. (1975). University Prestige and first-time undergraduate migration in the United States. Sociology of Education, 48 (2), 168-185.

Agarwal, V. B. and Winkler, D. R. (1985). Foreign Demand for United States Higher Education: A Study of Developing Countries in the Eastern Hemisphere, Economic Development and Cultural Change, 33 (3), 623-644

Aghion, P., Dewatripont, M., Hoxby, C., Mas-Collel, A. and Sapir, A. (2007). Why reform Europe's universities? Bruegel Policy Brief, issue 2007/4

Aslanbeigui, N. and Montecinos, V. (1998). Foreign Students in U.S. Doctoral Programs. Journal of Economic Perspectives, 12 (3), 171-182

Becker, G. (1964). Human Capital, New York: Columbia University Press

Bessey, D. (2007). International Student Migration to Germany, Swiss Leading House working paper no.6

Bourke, A. (2000). A Model of the Determinants of International Trade in Higher Education. The Service Industries Journal, 20 (1), 110-138

Brewer, D., Eide, E. R. and Ehrenberg, R.G. (1999). Does it pay to attend an elite private college? Cross-cohort evidence on the effects of college type on earnings. Journal of Human Resources, 34 (1), 104-123

Cummings, W. K. (1984). Going Overseas for Higher Education: The Asian Experience. Comparative Education Review, vol.28 (2), 241-257

Epple, D., Romano, R. and Sieg, H. (2006). Admission, Tuition and Financial Aid Policies in the Market for Higher Education. Econometrica, 74 (4), 885-928

Eurydice network, (2010), Focus on Higher Education in Europe 2010: The Impact of the Bologna Process, Education, Audiovisual and Culture Executive Agency (EACEA P9 Eurydice), ISBN 978-92-9201-086-7

Faggian, A., McCann, P. and Sheppard, S. (2007). Human Capital, Higher Education and Graduate Migration: an Analysis of Scottish and Welsh students. Urban Studies, 44 (13), 2511-2528

Freeman, R. (1986). Demand for Education. In Ashenfelter, O. and Layard, R. (ed.), Handbook of Labor Economics, vol.1, Elsevier, the Netherlands 
Gordon, J. and Jallade, J. (1996). Spontaneous' Student Mobility in the European Union: A Statistical Survey. European Journal of Education, 31 (2), 133-151

Hoxby, C. M. (2002). The Effects of Geographic Integration and Increasing Competition in the Market for College Education, mimeo, Department of Economics, Harvard University

Ince, M. (2007). The Times Higher Education Supplement: World University Rankings

Kemp, S., Madden, G. and Simpson, M. (1998). Emerging Australian Education Markets: A Discrete Choice Model of Taiwanese and Indonesian Student Intended Study Destination. Education Economis, 6 (2), 159-169

Kondakci, Y. (2010). Student Mobility Reviewed: Attraction and Satisfaction of International Students in Turkey. Higher Education, vol.62, no.5, pp.573-592

Krueger, A. and Lindahl, M. (2001). Education for Growth: Why and For Whom? Journal of Economic Literature, 39 (4), 1101-1136

Lee, K. H. and Tan, J. Peng (1984). The International Flow of Third Level Lesser Developed Country Students to Developed Countries: Determinants and Implications. Higher Education, 13 (6), 687-707

Mazzarol, T. and Soutar, G. (2000). "Push-pull" Factors Influencing International Students Destination Choice. The International Journal of Educational Management, 16 (2), 82-90

McCann, P. and Sheppard, S. (2002). An analysis of the Gender determinants of UK graduate migration behavior. Paper presented at the 42nd Congress of the European Regional Science Association, Dortmund

McMahon, M. E. (1992). Higher Education in a World Market. An Historical Look at the Global Context of International Study. Higher Education, 24 (4), 465-482

Musselin, Christine. (2004). Towards a European Academic Labour Market? Some Lessons Drawn from Empirical Studies on Academic Mobility. Higher Education, 48(1), $55-78$

Naidoo, Vikash, (2007). Research on the Flow of International Students to UK Universities: Determinants and Implications. Journal of Research in International Education, 6(3), 287-307 
Ono, H. (2001). Migration patterns among Japanese university students, paper presented at the Center for Economic Policy Research Conference of the European Network of the Japanese Economy, Oxford

Rodríguez González, C., R. Bustillo Mesanza and P. Mariel. (2011). The Determinants of International Student Mobility Flows: An Empirical Study of the Erasmus Programme. Higher Education, 62(4), 413-430

Sá, C. and Florax, R. J. G. M. (2004). Determinants of the Regional Demand for Higher Education in The Netherlands: A Gravity Model Approach. Regional Studies, 38 (4), 375 392

Spence, M. (1973). Job market signaling. Quarterly Journal of Economics, 87 (3), $355-$ 374

Szelényi, K. (2006). Students without Borders? Migratory Decision-Making among International Graduate Students in the U.S. Knowledge, Technology \& Policy, 19 (3), 6486

Thissen, L. and Ederveen, S. (2006). Higher education: Time for coordination on a European level? CPB discussion paper 


\section{Vitae}

Reinhilde Veugelers is professor of Managerial Economics, Strategy and Innovation at the Katholieke Universiteit Leuven. She was a visiting scholar at Northwestern University's Kellogg Graduate School of Management, at Sloan School of Management (MIT), Stern Business School (NYU), ECARES/Université Libre de Bruxelles, Université de Paris I (Panthéon-Sorbonne), Universitat Pompeu Fabra \& Universitat Autonoma de Barcelona, Universiteit Maastricht.

With her research concentrated in the fields of industrial organisation, international economics and strategy and innovation, she has authored numerous publications on multinationals, R\&D cooperation and alliances, industry-science links and market integration in leading international journals. She obtained research grants from the Belgian Science Policy Office, the European Commission (DG Research and DG ECFIN) and the Flemish Government (VRWB-IWT).

From 2004-2008, she was on academic leave, as advisor at the European Commission (BEPA). She is currently a Senior Fellow at Bruegel, a CEPR Research Fellow and a member of Commissioner Potocnik's Knowledge for Growth expert group. She is also copromotor for the Flemish Government "Steunpunt" on R\&D Statistics.

Linda Van Bouwel is a doctoral researcher at the Katholieke Universiteit Leuven. She is a member of the Department of Managerial Economics, Strategy and Innovation at the Faculty of Business and Economics. She was a visiting scholar at the Andrew Young School of Policy Studies (Georgia State University) in 2011. 
Figures and tables

Figure 1: Inflows, outflows and net inflows of foreign students (ISCED level 5A)

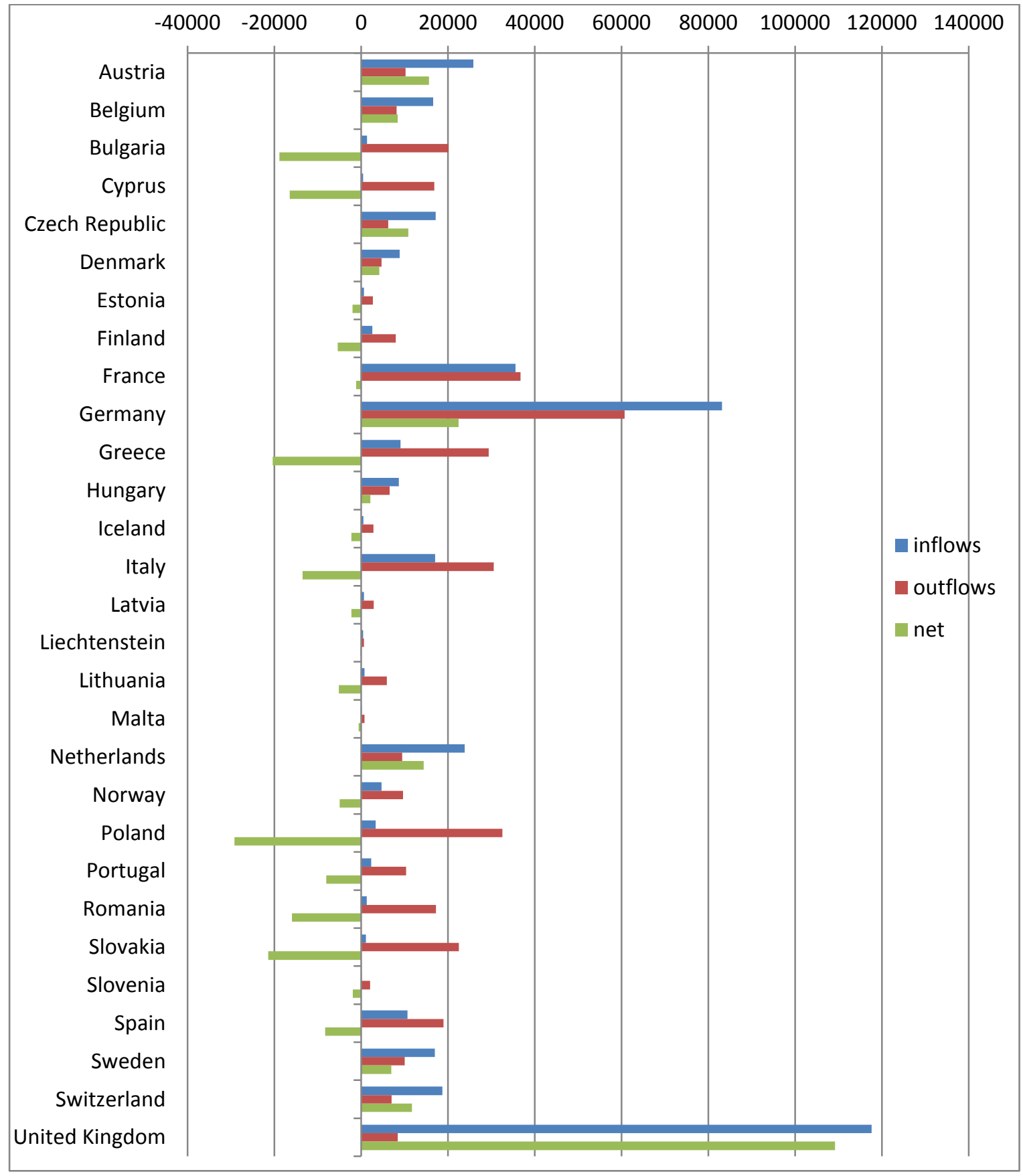


Figure 2: Inflows, outflows and net inflows of foreign graduate students (ISCED level 6)

\begin{tabular}{|r|r|r|}
\hline Austria & relgium \\
Bulgaria & \\
Switzerland \\
Cyprus \\
Czech Republic \\
Germany \\
Denmark \\
Estonia \\
Spain \\
Finland \\
France \\
Greece \\
Hungary \\
Ireland \\
Iceland \\
Italy
\end{tabular}


Table 1: Average student flows and quality indicators by country

\begin{tabular}{|c|c|c|c|c|}
\hline Country & $\begin{array}{l}\text { average } \\
\text { flow of } \\
\text { international } \\
\text { students }\end{array}$ & $\begin{array}{l}\text { relative } \\
\text { impact }\end{array}$ & $\begin{array}{l}\text { Shanghai } \\
\text { ranking } \\
\text { count }\end{array}$ & $\begin{array}{l}\text { THES } \\
\text { ranking } \\
\text { count }\end{array}$ \\
\hline Switzerland & 624.7 & 1.37 & 6 & 5 \\
\hline Netherlands & 822.41 & 1.15 & 9 & 11 \\
\hline Denmark & 306.48 & 1.1 & 3 & 3 \\
\hline Sweden & 584.76 & 1.07 & 4 & 4 \\
\hline UK & $4,045.21$ & 1.06 & 23 & 32 \\
\hline Finland & 88.24 & 1.05 & 1 & 2 \\
\hline Germany & $2,787.07$ & 1.03 & 14 & 11 \\
\hline Belgium & 546.34 & 0.96 & 4 & 5 \\
\hline France & $1,176.62$ & 0.96 & 7 & 5 \\
\hline Austria & 877.28 & 0.93 & 1 & 2 \\
\hline Italy & 585.79 & 0.92 & 5 & 2 \\
\hline Iceland & 18.79 & 0.9 & 0 & 0 \\
\hline Ireland & $\mathrm{n} / \mathrm{a}$ & 0.89 & 0 & 2 \\
\hline Norway & 162.72 & 0.84 & 1 & 1 \\
\hline Spain & 368.9 & 0.79 & 1 & 1 \\
\hline Estonia & 23.55 & 0.66 & 0 & 0 \\
\hline Hungary & 290.77 & 0.63 & 0 & 0 \\
\hline Portugal & 80.1 & 0.63 & 0 & 0 \\
\hline Slovenia & 4.47 & 0.58 & 0 & 0 \\
\hline Greece & 302.6 & 0.55 & 0 & 0 \\
\hline Czech Republic & 592.21 & 0.52 & 0 & 0 \\
\hline Cyprus & 14.86 & 0.51 & 0 & 0 \\
\hline Poland & 116.41 & 0.49 & 0 & 0 \\
\hline Lithuania & 27.72 & 0.46 & 0 & 0 \\
\hline Latvia & 22.2 & 0.43 & 0 & 0 \\
\hline Bulgaria & 46.1 & 0.37 & 0 & 0 \\
\hline Slovakia & 39.1 & 0.36 & 0 & 0 \\
\hline Romania & 43.82 & 0.32 & 0 & 0 \\
\hline Liechtenstein & 15.2 & $\mathrm{n} / \mathrm{a}$ & 0 & 0 \\
\hline Luxembourg & $\mathrm{n} / \mathrm{a}$ & $\mathrm{n} / \mathrm{a}$ & 0 & 0 \\
\hline Malta & 5.67 & $\mathrm{n} / \mathrm{a}$ & 0 & 0 \\
\hline Correlation with Shanghai ranking & & 0.50 & & \\
\hline Correlation with THES ranking & & 0.46 & 0.98 & \\
\hline
\end{tabular}


Table 2: Control variables by country

\begin{tabular}{|c|c|c|c|c|c|}
\hline Country & $\begin{array}{l}\text { student } \\
\text { population }\end{array}$ & $\begin{array}{l}\text { average } \\
\text { distance }\end{array}$ & $\begin{array}{l}\text { higher } \\
\text { education } \\
\text { expenditure }\end{array}$ & tuition fee & $\begin{array}{l}\text { educational } \\
\text { opportunities }\end{array}$ \\
\hline Austria & 219,691 & $1,080.34$ & $13,133.40$ & 824.79 & 0.75 \\
\hline Belgium & 185,363 & $1,207.52$ & $11,208.90$ & 546.50 & 0.76 \\
\hline Bulgaria & 226,923 & $1,509.57$ & $2,827.30$ & $\mathrm{n} / \mathrm{a}$ & 0.74 \\
\hline Cyprus & 4,989 & $2,534.52$ & $8,922.50$ & $\mathrm{n} / \mathrm{a}$ & 0.76 \\
\hline Czech Republic & 308,376 & $1,051.28$ & $6,825.10$ & 0.00 & 0.74 \\
\hline Denmark & 198,052 & $1,204.14$ & $13,689.30$ & 0.00 & 0.74 \\
\hline Spain & $1,468,942$ & $1,975.90$ & $10,300.60$ & 844.00 & 0.72 \\
\hline Estonia & 42,966 & $1,590.10$ & $4,339.10$ & $\mathrm{n} / \mathrm{a}$ & 0.74 \\
\hline Finland & 287,216 & $1,647.76$ & $11,278.60$ & 0.00 & 0.74 \\
\hline France & $1,567,977$ & $1,298.48$ & $10,618.80$ & $1,671.50$ & 0.74 \\
\hline Germany & $1,950,468$ & $1,082.31$ & $11,448.40$ & $\mathrm{n} / \mathrm{a}$ & 0.74 \\
\hline Greece & 367,439 & $1,804.84$ & $\mathrm{n} / \mathrm{a}$ & $\mathrm{n} / \mathrm{a}$ & 0.74 \\
\hline Hungary & 397,722 & $1,111.68$ & $\mathrm{n} / \mathrm{a}$ & $\mathrm{n} / \mathrm{a}$ & 0.74 \\
\hline Iceland & 15,320 & $2,778.93$ & $7,912.30$ & $1,815.35$ & 0.74 \\
\hline Ireland & 130,260 & $1,631.68$ & $10,501.40$ & 0.10 & 0.74 \\
\hline Italy & $1,983,005$ & $1,385.07$ & $7,210.90$ & $1,342.44$ & 0.74 \\
\hline Liechtenstein & 655 & $1,070.81$ & $8,295.40$ & $\mathrm{n} / \mathrm{a}$ & 0.74 \\
\hline Lithuania & 140,644 & $1,393.93$ & $4,652.30$ & $\mathrm{n} / \mathrm{a}$ & 0.72 \\
\hline Latvia & 108,458 & $1,432.76$ & $4,543.90$ & $\mathrm{n} / \mathrm{a}$ & 0.73 \\
\hline Luxembourg & $\mathrm{n} / \mathrm{a}$ & $1,087.29$ & $\mathrm{n} / \mathrm{a}$ & $\mathrm{n} / \mathrm{a}$ & 0.74 \\
\hline Malta & 8,336 & $1,814.71$ & $\mathrm{n} / \mathrm{a}$ & $\mathrm{n} / \mathrm{a}$ & 0.74 \\
\hline Netherlands & 582,613 & $1,208.48$ & $13,276.00$ & $1,707.00$ & 0.73 \\
\hline Norway & 207,776 & $1,492.90$ & $14,249.50$ & 614.88 & 0.73 \\
\hline Poland & $2,092,162$ & $1,192.17$ & $3,811.80$ & $\mathrm{n} / \mathrm{a}$ & 0.73 \\
\hline Portugal & 345,120 & $2,384.65$ & $7,939.80$ & $2,114.44$ & 0.73 \\
\hline Romania & 887,526 & $1,536.55$ & $4,239.30$ & $\mathrm{n} / \mathrm{a}$ & 0.74 \\
\hline Sweden & 371,307 & $1,452.14$ & $15,265.00$ & 0.00 & 0.74 \\
\hline Switzerland & 157,403 & $1,115.84$ & $\mathrm{n} / \mathrm{a}$ & $\mathrm{n} / \mathrm{a}$ & 0.74 \\
\hline Slovenia & 65,757 & $1,138.00$ & $5,955.10$ & 668.00 & 0.74 \\
\hline Slovakia & 204,645 & $1,092.52$ & $4,768.00$ & $\mathrm{n} / \mathrm{a}$ & 0.74 \\
\hline UK & $1,747,199$ & $1,387.10$ & $13,015.50$ & $4,694.00$ & 0.75 \\
\hline
\end{tabular}


Table 3

Basic gravity models

\begin{tabular}{|c|c|c|c|c|c|}
\hline VARIABLES & $\begin{array}{l}\text { (1) } \\
\text { lintstud5a }\end{array}$ & $\begin{array}{l}\text { (2) } \\
\text { lintstud5a }\end{array}$ & $\begin{array}{l}(3) \\
\text { lintstud5a }\end{array}$ & $\begin{array}{l}\text { (4) } \\
\text { lintstud5a }\end{array}$ & $\begin{array}{l}(5) \\
\text { lintstud5a }\end{array}$ \\
\hline student population - host & $\begin{array}{l}0.949 * * * \\
(0.0797)\end{array}$ & $\begin{array}{l}0.766 * * * \\
(0.0807)\end{array}$ & $\begin{array}{l}0.675 * * * \\
(0.0867)\end{array}$ & $\begin{array}{l}0.561 * * * \\
(0.109)\end{array}$ & $\begin{array}{l}0.746 * * * \\
(0.0868)\end{array}$ \\
\hline student population - sender & $\begin{array}{l}0.680 * * * \\
(0.0469)\end{array}$ & $\begin{array}{l}0.710 * * * \\
(0.0452)\end{array}$ & $\begin{array}{l}0.710 * * * \\
(0.0449)\end{array}$ & $\begin{array}{l}0.709 * * * \\
(0.0451)\end{array}$ & $\begin{array}{l}0.710 * * * \\
(0.0453)\end{array}$ \\
\hline distance & $\begin{array}{l}-0.733 * * * \\
(0.136)\end{array}$ & $\begin{array}{l}-0.726^{* * * *} \\
(0.134)\end{array}$ & $\begin{array}{l}-0.687 * * * \\
(0.135)\end{array}$ & $\begin{array}{l}-0.712 * * * \\
(0.136)\end{array}$ & $\begin{array}{l}-0.726 * * * \\
(0.134)\end{array}$ \\
\hline shared border & $\begin{array}{l}1.002 * * * \\
(0.344)\end{array}$ & $\begin{array}{l}0.881 * * * \\
(0.321)\end{array}$ & $\begin{array}{l}0.946^{* * *} \\
(0.323)\end{array}$ & $\begin{array}{l}0.935 * * * \\
(0.324)\end{array}$ & $\begin{array}{l}0.892 * * * \\
(0.325)\end{array}$ \\
\hline shared language & $\begin{array}{l}0.496 \\
(0.442)\end{array}$ & $\begin{array}{l}0.589 \\
(0.426)\end{array}$ & $\begin{array}{l}0.593 \\
(0.429)\end{array}$ & $\begin{array}{l}0.615 \\
(0.434)\end{array}$ & $\begin{array}{l}0.597 \\
(0.426)\end{array}$ \\
\hline higher education expenditure & & $\begin{array}{l}0.776^{*} \\
(0.424)\end{array}$ & $\begin{array}{l}1.013 * * \\
(0.414)\end{array}$ & $\begin{array}{l}1.125^{* * *} \\
(0.420)\end{array}$ & $\begin{array}{l}0.749 * \\
(0.430)\end{array}$ \\
\hline tuition fee & & $\begin{array}{l}-0.167 * * * \\
(0.0493)\end{array}$ & $\begin{array}{l}-0.195 * * * \\
(0.0506)\end{array}$ & $\begin{array}{l}-0.203 * * * \\
(0.0519)\end{array}$ & $\begin{array}{l}-0.172 * * * \\
(0.0506)\end{array}$ \\
\hline educational opportunities & & $\begin{array}{l}-0.425 \\
(0.304)\end{array}$ & $\begin{array}{l}-0.419 \\
(0.301)\end{array}$ & $\begin{array}{l}-0.423 \\
(0.301)\end{array}$ & $\begin{array}{l}-0.423 \\
(0.304)\end{array}$ \\
\hline relative impact & & & $\begin{array}{l}2.425 * * * \\
(0.785)\end{array}$ & & \\
\hline Shanghai ranking count & & & & $\begin{array}{l}0.110 * * * \\
(0.0357)\end{array}$ & \\
\hline THES ranking count & & & & & $\begin{array}{l}0.0228 \\
(0.0274)\end{array}$ \\
\hline host - Scandinavia & $\begin{array}{l}-0.142 \\
(0.177)\end{array}$ & $\begin{array}{l}-1.844 * * * \\
(0.495)\end{array}$ & $\begin{array}{l}-2.344 * * * \\
(0.522)\end{array}$ & $\begin{array}{l}-2.010^{* * *} \\
(0.502)\end{array}$ & $\begin{array}{l}-1.837 * * * \\
(0.495)\end{array}$ \\
\hline host - Mediterranean & $\begin{array}{l}-1.256^{* * * *} \\
(0.187)\end{array}$ & $\begin{array}{l}-0.774 * * * \\
(0.244)\end{array}$ & $\begin{array}{l}-0.0758 \\
(0.315)\end{array}$ & $\begin{array}{l}-0.0949 \\
(0.329)\end{array}$ & $\begin{array}{l}-0.653 * * \\
(0.282)\end{array}$ \\
\hline host - new member state & $\begin{array}{l}-2.526^{* * * *} \\
(0.294)\end{array}$ & $\begin{array}{l}-3.035 * * * \\
(0.434)\end{array}$ & $\begin{array}{l}-2.013 * * * \\
(0.522)\end{array}$ & $\begin{array}{l}-2.620 * * * \\
(0.440)\end{array}$ & $\begin{array}{l}-2.968 * * * \\
(0.432)\end{array}$ \\
\hline host - non EU & $\begin{array}{l}0.365 \\
(0.250)\end{array}$ & $\begin{array}{l}1.793 * * * \\
(0.489)\end{array}$ & $\begin{array}{l}2.445^{* * *} \\
(0.540)\end{array}$ & $\begin{array}{l}2.116 * * * \\
(0.505)\end{array}$ & $\begin{array}{l}1.864 * * * \\
(0.504)\end{array}$ \\
\hline host - English speaking & $\begin{array}{l}1.366 * * * \\
(0.261)\end{array}$ & $\begin{array}{l}1.784 * * * \\
(0.278)\end{array}$ & $\begin{array}{l}1.782 * * * \\
(0.280)\end{array}$ & $\begin{array}{l}0.129 \\
(0.572)\end{array}$ & $\begin{array}{l}1.223 * \\
(0.683)\end{array}$ \\
\hline sender - Scandinavia & $\begin{array}{l}0.311 \\
(0.209)\end{array}$ & $\begin{array}{l}0.410 * \\
(0.215)\end{array}$ & $\begin{array}{l}0.397 * \\
(0.213)\end{array}$ & $\begin{array}{l}0.411^{*} \\
(0.212)\end{array}$ & $\begin{array}{l}0.412 * \\
(0.215)\end{array}$ \\
\hline sender - Mediterranean & $\begin{array}{l}0.353 \\
(0.248)\end{array}$ & $\begin{array}{l}0.540 * \\
(0.281)\end{array}$ & $\begin{array}{l}0.514^{*} \\
(0.281)\end{array}$ & $\begin{array}{l}0.537^{*} \\
(0.280)\end{array}$ & $\begin{array}{l}0.541 * \\
(0.281)\end{array}$ \\
\hline sender - new member state & $\begin{array}{l}0.274 \\
(0.169)\end{array}$ & $\begin{array}{l}0.404 * * \\
(0.197)\end{array}$ & $\begin{array}{l}0.396 * * \\
(0.196)\end{array}$ & $\begin{array}{l}0.408 * * \\
(0.195)\end{array}$ & $\begin{array}{l}0.406 * * \\
(0.197)\end{array}$ \\
\hline sender - non EU & $\begin{array}{l}0.339 \\
(0.253)\end{array}$ & $\begin{array}{l}0.378 \\
(0.243)\end{array}$ & $\begin{array}{l}0.378 \\
(0.239)\end{array}$ & $\begin{array}{l}0.377 \\
(0.238)\end{array}$ & $\begin{array}{l}0.378 \\
(0.243)\end{array}$ \\
\hline sender - English speaking & $\begin{array}{l}-0.00297 \\
(0.238)\end{array}$ & $\begin{array}{l}0.0505 \\
(0.210)\end{array}$ & $\begin{array}{l}0.0494 \\
(0.211)\end{array}$ & $\begin{array}{l}0.0565 \\
(0.208)\end{array}$ & $\begin{array}{l}0.0526 \\
(0.210)\end{array}$ \\
\hline Constant & $\begin{array}{l}-10.62 * * * \\
(1.604)\end{array}$ & $\begin{array}{l}-14.61 * * * \\
(4.369)\end{array}$ & $\begin{array}{l}-18.18^{* * * *} \\
(4.276)\end{array}$ & $\begin{array}{l}-15.67 * * * \\
(4.262)\end{array}$ & $\begin{array}{l}-14.19 * * * \\
(4.457)\end{array}$ \\
\hline Observations & 435 & 435 & 435 & 435 & 435 \\
\hline R-squared & 0.759 & 0.773 & 0.776 & 0.776 & 0.773 \\
\hline
\end{tabular}

Notes: Robust t statistics in parentheses; * significant at 10\%; ** significant at 5\%; *** significant at $1 \%$ 
Table 4

Relative gravity models

\begin{tabular}{|c|c|c|c|}
\hline VARIABLES & $\begin{array}{l}\text { (1) } \\
\text { lintstud5a }\end{array}$ & $\begin{array}{l}\text { (2) } \\
\text { lintstud5a }\end{array}$ & $\begin{array}{l}(3) \\
\text { lintstud5a }\end{array}$ \\
\hline student population - host & $\begin{array}{l}0.821 * * * \\
(0.118)\end{array}$ & $\begin{array}{l}0.766^{* * * *} \\
(0.120)\end{array}$ & $\begin{array}{l}0.798 * * * \\
(0.115)\end{array}$ \\
\hline student population - sender & $\begin{array}{l}0.656 * * * \\
(0.110)\end{array}$ & $\begin{array}{l}0.701 * * * \\
(0.114)\end{array}$ & $\begin{array}{l}0.679 * * * \\
(0.110)\end{array}$ \\
\hline distance & $\begin{array}{l}-1.079 * * * \\
(0.181)\end{array}$ & $\begin{array}{l}-1.111^{* * *} \\
(0.181)\end{array}$ & $\begin{array}{l}-1.099 * * * \\
(0.182)\end{array}$ \\
\hline shared border & $\begin{array}{l}0.580 * \\
(0.296)\end{array}$ & $\begin{array}{l}0.571 * \\
(0.295)\end{array}$ & $\begin{array}{l}0.575^{*} \\
(0.298)\end{array}$ \\
\hline shared language & $\begin{array}{l}0.202 \\
(0.398)\end{array}$ & $\begin{array}{l}0.224 \\
(0.389)\end{array}$ & $\begin{array}{l}0.218 \\
(0.399)\end{array}$ \\
\hline relative higher education expenditure & $\begin{array}{l}0.672 * \\
(0.381)\end{array}$ & $\begin{array}{l}0.749 * \\
(0.395)\end{array}$ & $\begin{array}{l}0.702 * \\
(0.394)\end{array}$ \\
\hline relative tuition fee & $\begin{array}{l}0.000135 \\
(9.32 \mathrm{e}-05)\end{array}$ & $\begin{array}{l}0.000112 \\
(9.14 \mathrm{e}-05)\end{array}$ & $\begin{array}{l}0.000131 \\
(9.40 \mathrm{e}-05)\end{array}$ \\
\hline relative educational opportunities & $\begin{array}{l}0.00832 \\
(0.118)\end{array}$ & $\begin{array}{l}0.0242 \\
(0.118)\end{array}$ & $\begin{array}{l}0.00769 \\
(0.118)\end{array}$ \\
\hline relative relative impact & $\begin{array}{l}-0.476 \\
(0.566)\end{array}$ & & \\
\hline relative SR count & & $\begin{array}{l}0.0344 * \\
(0.0194)\end{array}$ & \\
\hline relative THES count & & & $\begin{array}{l}0.0152 \\
(0.0169)\end{array}$ \\
\hline host - Scandinavia & $\begin{array}{l}0.228 \\
(0.239)\end{array}$ & $\begin{array}{l}0.213 \\
(0.228)\end{array}$ & $\begin{array}{l}0.205 \\
(0.232)\end{array}$ \\
\hline host - Mediterranean & $\begin{array}{l}-0.868 * * * \\
(0.320)\end{array}$ & $\begin{array}{l}-0.584 * \\
(0.329)\end{array}$ & $\begin{array}{l}-0.659 * * \\
(0.323)\end{array}$ \\
\hline host - new member state & $\begin{array}{l}-2.809^{* * *} \\
(0.478)\end{array}$ & $\begin{array}{l}-2.466^{* * *} \\
(0.437)\end{array}$ & $\begin{array}{l}-2.522 * * * \\
(0.437)\end{array}$ \\
\hline host - non EU & $\begin{array}{l}0.161 \\
(0.379)\end{array}$ & $\begin{array}{l}0.267 \\
(0.354)\end{array}$ & $\begin{array}{l}0.270 \\
(0.354)\end{array}$ \\
\hline host - English speaking & $\begin{array}{l}1.252 * * * \\
(0.253)\end{array}$ & $\begin{array}{l}0.890 * * * \\
(0.294)\end{array}$ & $\begin{array}{l}1.005 * * * \\
(0.365)\end{array}$ \\
\hline sender - Scandinavia & $\begin{array}{l}0.222 \\
(0.276)\end{array}$ & $\begin{array}{l}0.310 \\
(0.268)\end{array}$ & $\begin{array}{l}0.268 \\
(0.271)\end{array}$ \\
\hline sender - Mediterranean & $\begin{array}{l}0.432 \\
(0.408)\end{array}$ & $\begin{array}{l}0.218 \\
(0.406)\end{array}$ & $\begin{array}{l}0.240 \\
(0.410)\end{array}$ \\
\hline sender - new member state & $\begin{array}{l}-0.500 \\
(0.510)\end{array}$ & $\begin{array}{l}-0.927^{* *} \\
(0.415)\end{array}$ & $\begin{array}{l}-0.903 * * \\
(0.417)\end{array}$ \\
\hline sender - non EU & $\begin{array}{l}0.794 * \\
(0.429)\end{array}$ & $\begin{array}{l}0.675^{*} \\
(0.404)\end{array}$ & $\begin{array}{l}0.690^{*} \\
(0.409)\end{array}$ \\
\hline sender - English speaking & $\begin{array}{l}0.00638 \\
(0.269)\end{array}$ & $\begin{array}{l}-0.0140 \\
(0.272)\end{array}$ & $\begin{array}{l}-0.0104 \\
(0.273)\end{array}$ \\
\hline Constant & $\begin{array}{l}-6.653 * * \\
(2.813)\end{array}$ & $\begin{array}{l}-6.995 * * \\
(2.759)\end{array}$ & $\begin{array}{l}-7.068 * * \\
(2.773)\end{array}$ \\
\hline $\begin{array}{l}\text { Observations } \\
\text { R-squared }\end{array}$ & $\begin{array}{l}225 \\
0.760\end{array}$ & $\begin{array}{l}225 \\
0.761\end{array}$ & $\begin{array}{l}225 \\
0.760\end{array}$ \\
\hline
\end{tabular}

Notes: Robust t statistics in parentheses; * significant at 10\%; ** significant at 5\%; *** significant at $1 \%$ 
Table 5

ISCED level 6

\begin{tabular}{|c|c|c|c|c|c|c|}
\hline VARIABLES & $\begin{array}{l}(1) \\
\text { lintstud6 }\end{array}$ & $\begin{array}{l}(2) \\
\text { lintstud6 }\end{array}$ & $\begin{array}{l}(3) \\
\text { lintstud6 }\end{array}$ & $\begin{array}{l}(4) \\
\text { lintstud5a }\end{array}$ & $\begin{array}{l}(5) \\
\text { lintstud5a }\end{array}$ & $\begin{array}{l}(6) \\
\text { lintstud5a }\end{array}$ \\
\hline student population (graduate) - host & $\begin{array}{l}0.859 * * * \\
(0.0799)\end{array}$ & $\begin{array}{l}0.807 * * * \\
(0.0854)\end{array}$ & $\begin{array}{l}0.835 * * * \\
(0.0806)\end{array}$ & $\begin{array}{l}0.627 * * * \\
(0.0911)\end{array}$ & $\begin{array}{l}0.365 * * * \\
(0.133)\end{array}$ & $\begin{array}{l}0.656^{* * * *} \\
(0.111)\end{array}$ \\
\hline student population (graduate) - sender & $\begin{array}{l}0.545 * * * \\
(0.0393)\end{array}$ & $\begin{array}{l}0.546 * * * \\
(0.0394)\end{array}$ & $\begin{array}{l}0.545 * * * \\
(0.0395)\end{array}$ & $\begin{array}{l}0.698 * * * \\
(0.0483)\end{array}$ & $\begin{array}{l}0.696 * * * \\
(0.0487)\end{array}$ & $\begin{array}{l}0.694 * * * \\
(0.0494)\end{array}$ \\
\hline distance & $\begin{array}{l}-0.539 * * * \\
(0.133)\end{array}$ & $\begin{array}{l}-0.529 * * * \\
(0.134)\end{array}$ & $\begin{array}{l}-0.537 * * * \\
(0.133)\end{array}$ & $\begin{array}{l}-0.729 * * * \\
(0.142)\end{array}$ & $\begin{array}{l}-0.770 * * * \\
(0.144)\end{array}$ & $\begin{array}{l}-0.803 * * * \\
(0.141)\end{array}$ \\
\hline shared border & $\begin{array}{l}1.078 * * * \\
(0.297)\end{array}$ & $\begin{array}{l}1.098 * * * \\
(0.301)\end{array}$ & $\begin{array}{l}1.101 * * * \\
(0.302)\end{array}$ & $\begin{array}{l}0.875^{* *} \\
(0.363)\end{array}$ & $\begin{array}{l}0.879 * * \\
(0.368)\end{array}$ & $\begin{array}{l}0.824 * * \\
(0.370)\end{array}$ \\
\hline shared language & $\begin{array}{l}0.119 \\
(0.297)\end{array}$ & $\begin{array}{l}0.119 \\
(0.302)\end{array}$ & $\begin{array}{l}0.103 \\
(0.307)\end{array}$ & $\begin{array}{l}0.592 \\
(0.468)\end{array}$ & $\begin{array}{l}0.600 \\
(0.484)\end{array}$ & $\begin{array}{l}0.613 \\
(0.487)\end{array}$ \\
\hline higher education expenditure & $\begin{array}{l}0.665 \\
(0.470)\end{array}$ & $\begin{array}{l}0.825^{*} \\
(0.464)\end{array}$ & $\begin{array}{l}0.626 \\
(0.444)\end{array}$ & $\begin{array}{l}1.439 * * * \\
(0.465)\end{array}$ & $\begin{array}{l}1.807 * * * \\
(0.493)\end{array}$ & $\begin{array}{l}0.885^{*} \\
(0.451)\end{array}$ \\
\hline tuition fee & $\begin{array}{l}0.0744 \\
(0.0519)\end{array}$ & $\begin{array}{l}0.0628 \\
(0.0526)\end{array}$ & $\begin{array}{l}0.0710 \\
(0.0518)\end{array}$ & $\begin{array}{l}-0.204 * * * \\
(0.0520)\end{array}$ & $\begin{array}{l}-0.223 * * * \\
(0.0535)\end{array}$ & $\begin{array}{l}-0.186 * * * \\
(0.0522)\end{array}$ \\
\hline educational opportunities (graduate) & $\begin{array}{l}-15.88 * * * \\
(2.949)\end{array}$ & $\begin{array}{l}-15.99 * * * \\
(2.938)\end{array}$ & $\begin{array}{l}-15.96 * * * \\
(2.939)\end{array}$ & $\begin{array}{l}-0.454 \\
(0.313)\end{array}$ & $\begin{array}{l}-0.465 \\
(0.312)\end{array}$ & $\begin{array}{l}-0.459 \\
(0.318)\end{array}$ \\
\hline relative impact & $\begin{array}{l}0.657 \\
(1.008)\end{array}$ & & & $\begin{array}{l}4.369 * * * \\
(1.190)\end{array}$ & & \\
\hline Shanghai ranking count & & $\begin{array}{l}0.0594 * \\
(0.0351)\end{array}$ & & & $\begin{array}{l}0.230 * * * \\
(0.0556)\end{array}$ & \\
\hline THES ranking count & & & $\begin{array}{l}0.105 * \\
(0.0630)\end{array}$ & & & $\begin{array}{l}0.157 * \\
(0.0921)\end{array}$ \\
\hline host - Scandinavia & $\begin{array}{l}0.588 \\
(0.523)\end{array}$ & $\begin{array}{l}0.601 \\
(0.496)\end{array}$ & $\begin{array}{l}0.739 \\
(0.497)\end{array}$ & $\begin{array}{l}-2.848 * * * \\
(0.561)\end{array}$ & $\begin{array}{l}-2.308 * * * \\
(0.524)\end{array}$ & $\begin{array}{l}-1.907 * * * \\
(0.510)\end{array}$ \\
\hline host - Mediterranean & $\begin{array}{l}-0.713 * * \\
(0.333)\end{array}$ & $\begin{array}{l}-0.614 * * \\
(0.281)\end{array}$ & $\begin{array}{l}-0.506 \\
(0.316)\end{array}$ & $\begin{array}{l}0.320 \\
(0.357)\end{array}$ & $\begin{array}{l}0.447 \\
(0.368)\end{array}$ & $\begin{array}{l}-0.144 \\
(0.424)\end{array}$ \\
\hline host - new member state & $\begin{array}{l}-0.794 \\
(0.649)\end{array}$ & $\begin{array}{l}-0.836 * \\
(0.466)\end{array}$ & $\begin{array}{l}-0.705 \\
(0.504)\end{array}$ & $\begin{array}{l}-1.163^{*} \\
(0.668)\end{array}$ & $\begin{array}{l}-2.116^{* * * *} \\
(0.481)\end{array}$ & $\begin{array}{l}-2.525 * * * \\
(0.528)\end{array}$ \\
\hline host - non EU & $\begin{array}{l}-0.0854 \\
(0.513)\end{array}$ & $\begin{array}{l}-0.0811 \\
(0.462)\end{array}$ & $\begin{array}{l}0.00515 \\
(0.472)\end{array}$ & $\begin{array}{l}2.937 * * * \\
(0.574)\end{array}$ & $\begin{array}{l}2.414 * * * \\
(0.516)\end{array}$ & $\begin{array}{l}2.229 * * * \\
(0.546)\end{array}$ \\
\hline host - English speaking & $\begin{array}{l}1.320 * * * \\
(0.309)\end{array}$ & $\begin{array}{l}0.329 \\
(0.690)\end{array}$ & $\begin{array}{l}-1.499 \\
(1.774)\end{array}$ & $\begin{array}{l}1.490 * * * \\
(0.320)\end{array}$ & $\begin{array}{l}-2.047 * * \\
(0.970)\end{array}$ & $\begin{array}{l}-2.424 \\
(2.510)\end{array}$ \\
\hline sender - Scandinavia & $\begin{array}{l}-0.204 \\
(0.208)\end{array}$ & $\begin{array}{l}-0.207 \\
(0.206)\end{array}$ & $\begin{array}{l}-0.205 \\
(0.207)\end{array}$ & $\begin{array}{l}0.536 * * \\
(0.233)\end{array}$ & $\begin{array}{l}0.558 * * \\
(0.229)\end{array}$ & $\begin{array}{l}0.570 * * \\
(0.234)\end{array}$ \\
\hline sender - Mediterranean & $\begin{array}{l}0.695 * * * \\
(0.226)\end{array}$ & $\begin{array}{l}0.689 * * * \\
(0.226)\end{array}$ & $\begin{array}{l}0.693 * * * \\
(0.224)\end{array}$ & $\begin{array}{l}0.687 * * \\
(0.308)\end{array}$ & $\begin{array}{l}0.723 * * \\
(0.306)\end{array}$ & $\begin{array}{l}0.745^{* *} \\
(0.307)\end{array}$ \\
\hline sender - new member state & $\begin{array}{l}0.0264 \\
(0.167)\end{array}$ & $\begin{array}{l}0.0240 \\
(0.167)\end{array}$ & $\begin{array}{l}0.0256 \\
(0.167)\end{array}$ & $\begin{array}{l}0.550 * * \\
(0.215)\end{array}$ & $\begin{array}{l}0.569 * * * \\
(0.212)\end{array}$ & $\begin{array}{l}0.576^{* * * *} \\
(0.214)\end{array}$ \\
\hline sender - non EU & $\begin{array}{l}0.0307 \\
(0.239)\end{array}$ & $\begin{array}{l}0.0297 \\
(0.237)\end{array}$ & $\begin{array}{l}0.0299 \\
(0.238)\end{array}$ & $\begin{array}{l}0.432 * \\
(0.256)\end{array}$ & $\begin{array}{l}0.431 * \\
(0.253)\end{array}$ & $\begin{array}{l}0.431 * \\
(0.259)\end{array}$ \\
\hline sender - English speaking & $\begin{array}{l}-0.297 \\
(0.185)\end{array}$ & $\begin{array}{l}-0.298 \\
(0.183)\end{array}$ & $\begin{array}{l}-0.296 \\
(0.183)\end{array}$ & $\begin{array}{l}0.224 \\
(0.237)\end{array}$ & $\begin{array}{l}0.239 \\
(0.230)\end{array}$ & $\begin{array}{l}0.243 \\
(0.231)\end{array}$ \\
\hline Constant & $\begin{array}{l}-13.37 * * * \\
(4.998)\end{array}$ & $\begin{array}{l}-13.96^{* * *} \\
(4.513)\end{array}$ & $\begin{array}{l}-12.55^{* * *} \\
(4.349)\end{array}$ & $\begin{array}{l}-22.88 * * * \\
(5.041)\end{array}$ & $\begin{array}{l}-19.33 * * * \\
(4.672)\end{array}$ & $\begin{array}{l}-14.12 * * * \\
(4.593)\end{array}$ \\
\hline Observations & 392 & 392 & 392 & 392 & 392 & 392 \\
\hline R-squared & 0.766 & 0.767 & 0.767 & 0.770 & 0.772 & 0.765 \\
\hline
\end{tabular}

Notes: Robust t statistics in parentheses; * significant at 5\%; ** significant at $1 \%$ 
